\title{
U-Pb Zircon Dating of Migmatitic Paragneisses and Garnet Amphibolite from the High Pressure Seve Nappe Complex in Kittelfjäll, Swedish Caledonides
}

\author{
Michał Bukała ${ }^{1,2, *(\mathbb{D})}$, Jarosław Majka ${ }^{1,3}$, Katarzyna Walczak ${ }^{1}\left({ }^{1}\right.$, Adam Włodek $^{1}{ }^{\circledR}$, \\ Melanie Schmitt ${ }^{4}$ (I) and Anna Zagórska ${ }^{5}$ \\ 1 Faculty of Geology, Geophysics and Environmental Protection, AGH-University of Science and Technology, \\ 30-059 Kraków, Poland; jmajka@agh.edu.pl (J.M.); kwalczak@agh.edu.pl (K.W.); wlodek@agh.edu.pl (A.W.) \\ 2 Instituto Andaluz de Ciencias de la Tierra, CSIC \& Universidad de Granada, 18100 Armilla, Granada, Spain \\ 3 Department of Earth Sciences, Uppsala University, 75236 Uppsala, Sweden \\ 4 Department of Geosciences, Swedish Museum of Natural History, 10405 Stockholm, Sweden; \\ Melanie.Schmitt@nrm.se \\ 5 Institute of Geological Sciences, Polish Academy of Sciences, Kraków Research Centre, 31-002 Kraków, \\ Poland; a.zagorska@ingpan.krakow.pl \\ * Correspondence: bukala@agh.edu.pl
}

Received: 17 February 2020; Accepted: 23 March 2020; Published: 25 March 2020

\begin{abstract}
The Seve Nappe Complex exposed in the Kittelfjäll area of the northern Scandinavian Caledonides comprises a volcano-sedimentary succession representing the Baltica passive margin, which was metamorphosed during the Iapetus Ocean closure. Garnet amphibolites, together with their host migmatitic paragneisses, record a potential (U)HP event followed by decompression-driven migmatization. The garnet amphibolites were originally thought to represent retrogressively altered granulites. The petrological and geochemical features of a studied garnet amphibolite allow for speculation about a peridotitic origin. Zirconium $(\mathrm{Zr})$ content in rutile inclusions hosted in garnet in paragneisses points to near-peak temperatures between $738^{\circ} \mathrm{C}$ and $780^{\circ} \mathrm{C}$, which is in agreement with the c. $774{ }^{\circ} \mathrm{C}$ obtained from the matrix rutile in the garnet amphibolite. The matrix rutile in multiple paragneiss samples records temperatures below $655^{\circ} \mathrm{C}$ and $726^{\circ} \mathrm{C}$. Whereas the LA-ICP-MS $\mathrm{U}-\mathrm{Pb}$ dating of zircon cores revealed the age spectrum from Paleoproterozoic to early Paleozoic, suggesting a detrital origin of zircon cores in paragneisses, the metamorphic zircon rims show an Early Ordovician cluster c. 475-469 Ma. Additionally, zircon cores and rims from the garnet amphibolite yielded an age of c. $473 \mathrm{Ma}$. The REE patterns of the Caledonian zircon rims from the paragneisses show overall low LREE concentrations, different from declining to rising trends in HREE $\left(\mathrm{Lu}_{\mathrm{N}} / \mathrm{Gd}_{\mathrm{N}}=0.49-38.76\right)$. Despite the textural differences, the cores and rims in zircon from the garnet amphibolite show similar REE patterns of low LREE and flat to rising HREE $\left(\mathrm{Lu}_{\mathrm{N}} / \mathrm{Gd}_{\mathrm{N}}=3.96-65.13\right)$. All zircon rims in both lithologies display a negative Eu anomaly. Hence, we interpret the reported ages as the growth of metamorphic zircon during migmatization, under granulite facies conditions related to exhumation from $(\mathrm{U}) \mathrm{HP}$ conditions.
\end{abstract}

Keywords: geochronology; subduction; metamorphism; migmatite; decompression

\section{Introduction}

The Scandinavian Caledonides represent a Paleozoic collisional orogen formed due to closure of the Iapetus ocean and subsequent collision between Laurentia and Baltica [1,2]. Prior to the collision, the Baltica passive margin (profusely intruded by dolerite dykes [3,4]), as well as the Iapteus plate, were subducted and subsequently exhumed and thrust onto the Baltic Shield (Gee et al., [5] and references 
therein). Structurally, the Scandinavian Caledonides comprise a series of allochthonous thrust sheets emplaced in an eastward direction, in contrast to the Greenland Caledonides, which record the opposite, westward direction of thrusting onto Laurentia [6]. The tectonostratigraphy of the Scandinavian Caledonides is divided into the Autochthon and the Lower, Middle, Upper and Uppermost allochthons. The Autochthon represents the Baltic Shield, while the Lower and Middle allochthons constitute the inner and outer Baltica passive margin, respectively. The Upper Allochthon comprises rocks with Iapetus affinity, while the Uppermost Allochthon is composed of Laurentia-derived terranes (Figure 1a).

(Ultra) high-pressure ((U)HP) rocks, which are important tracers of subduction processes, have been reported in the Scandinavian Caledonides from different tectonostratigraphic levels including the Middle and Uppermost allochthons, as well as the Parautochthon (i.e., the Autochthon buried and reworked during the latest stages of the Caledonian orogeny) [5]. In the Parautochthon, (U)HP rocks have been recognized in the Western Gneiss Region and Lofoten [7,8]. On the other hand, the (U)HP Tromsø Nappe of the Uppermost Allochthon is thought to represent either an exotic terrane of near-Laurentia origin [9] or an out-of-sequence thrust with its counterparts in the Middle Allochthon $[10,11]$. The unit with the most frequent occurrences of (U)HP rock is the upper part of the Middle Allochthon, particularly the Seve Nappe Complex (SNC) in Sweden, and its Norwegian equivalent, the Blåhø Nappe. The Middle Allochthon records an increasing metamorphic grade (from greenschist to amphibolite/granulite facies) towards the top of this sequence, but the highest grade metamorphic conditions (reaching up to eclogite facies) have been identified only within the SNC [5]. The SNC can be traced at a distance of approximately $800 \mathrm{~km}$ along the strike of the orogen [12,13]; thus, it provides a unique insight into a record of subduction processes operating along the entire orogen.

While the SNC lithologies exposed in Jämtland have an established history of $(\mathrm{U}) \mathrm{HP}$ metamorphism of Late Ordovician/ early Silurian age, e.g., [14-18], the (U)HP rocks known from Norrbotten [19,20] recording late Cambrian/Early Ordovician metamorphism are less extensively dated [21-23]. Even less well constrained are the timing and conditions of metamorphism within the SNC in Västerbotten (Figure 1a). The U-Pb dating of zircon from Gardiken, c. $25 \mathrm{~km}$ north of the study area, suggested a Late Ordovician age of granulite facies metamorphism [24]. Recently, Petrík et al. [25] provided evidence for Early Ordovician (U)HP metamorphism in Saxnäs, located c. $30 \mathrm{~km}$ south of the target area, while Grimmer et al. [26] estimated that exhumation to mid-crustal levels took place in the Llandovery and Wenlock. Thus, the main aim of this study is to fill this age gap of (U)HP metamorphism in the Middle Seve Nappe of Västerbotten, by coupling U-Pb zircon dating with rare earth elements (REE) analyses and trace elements (Zr-in-rutile) thermometry. We also provide insight into zircon behaviour during the migmatization of SNC paragneisses and garnet amphibolite. In a broader perspective, these age estimates allow for the revision of already existing models for subduction along the Baltoscandian margin and, more precisely, for defining the spatial and temporal boundary between the northern and central parts of the SNC in the Scandinavian Caledonides.

\section{Geological Setting}

The (U)HP metamorphic conditions recorded by SNC cropping out in west-central Jämtland have been established by the discovery of metamorphic microdiamonds in paragneisses at Tväråklumparna [27] (Figure 1a), and subsequently in a similar migmatitic paragneisses at Åreskutan. The latter experienced (U)HP metamorphism at 4.1-4.2 GPa and $830-840{ }^{\circ} \mathrm{C}$, followed by a granulite facies overprint at $1.0-1.1 \mathrm{GPa}$ and $850-860{ }^{\circ} \mathrm{C}[14,28]$. The age of the prograde to near-peak metamorphism has been estimated to c. $455 \mathrm{Ma}$, based on in-situ monazite dating [29]. Several zircon $\mathrm{U}-\mathrm{Pb}$ studies have shown that decompression-driven migmatization took place around $442-440 \mathrm{Ma}$ in migmatites and leucogranites and around $436 \mathrm{Ma}$ in partially melted amphibolites $[18,24,30]$, which is in line with titanite U-Pb ages [31]. Recently, Klonowska et al. [14] reported c. $445 \mathrm{Ma}$ and c. $441 \mathrm{Ma}$ Th-U-Pb monazite ages from both, Tväråklumparna and Åreskutan, reflecting post-(U)HP exhumation of paragneisses. These ages corroborate c. 439-438 Ma monazite ages interpreted as the timing of late melt crystallization [29]. The youngest group of zircon U-Pb ages (c. 430-428 Ma) was obtained 
from pegmatites, discordant to the migmatitic foliation that are deformed by later thrusting [18]. This thrusting event was dated to c. 424-423 Ma using Th-U-Pb monazite geochronology and reflects the timing of tectonic stacking of the Seve nappes [29].

Recently, (U)HP metamorphism has been confirmed also farther north in Norrbotten, on eclogites and metasedimentary rocks from the so-called Vaimok lens with peak pressure conditions at 2.8-3.1 GPa and $660-780^{\circ} \mathrm{C}$ [20] (Figure 1a). This confirmed previous speculations about the possible continuation of the SNC (U)HP lithologies north of the Arctic circle [19]. While the overlying Sarek lens does not show obvious signs of metamorphism exceeding amphibolite facies, the Tsäkkok lens records blueschist to eclogite facies metamorphism with a minimum pressure of 1.2-1.4 GPa and 500-630 ${ }^{\circ} \mathrm{C}$ [32-34], more recently updated to $2.2 \mathrm{GPa}$ and $590 \pm 60^{\circ} \mathrm{C}$ [35]. The previous studies established the age of prograde metamorphism of the Vaimok lens at 500-475 Ma [36], based on titanite U-Pb dating in calc-silicate rocks. This age was recently confirmed by Barnes et al. [23] who reported c. $498 \mathrm{Ma}$ prograde monazite growth in similar metasediments. Mørk et al. [21] estimated the timing of eclogite facies metamorphism at c. $505 \mathrm{Ma}$ using the garnet-omphacite-whole rock Sm-Nd isochrone. However, zircon U-Pb dating of eclogites yielded a younger age of c. $482 \mathrm{Ma}$ from both the Vaimok and Tsäkkok lenses [22]. Such age, in turn, is in line with those derived for the Vaimok metasediments showing a formation of HP metamorphic zircon rims at c. 480-475 Ma [23]. The timing of subsequent exhumation and related cooling was estimated with ${ }^{40} \mathrm{Ar} /{ }^{39} \mathrm{Ar}$ geochronology at $<468 \mathrm{Ma}$ [2]. A common phenomenon for the SNC in Norrbotten is that they record (U)HP metamorphism without a trace of granulite facies overprint and related migmatization, which is in severe contrast to the SNC lithologies in Jämtland and Västerbotten.

In northern Jämtland and southern Västerbotten (Figure 1b), the SNC is subdivided into the Lower, Middle, and Upper Seve Nappes that display relatively minor lithological differences [37]. Lower and Middle Seve are lithologically similar and consist of garnet- and kyanite-bearing mica schists, paragneisses, quartzites, marbles, garnet amphibolites (commonly retrogressed granulites) and, locally, eclogites and garnet-bearing ultramafics [38]. Traditionally, the boundary between Middle and Lower Seve was supposed to represent a significant break in metamorphic grade [39], but recent studies yielded broadly similar (U)HP conditions in both units [40-44]. The Tjeliken eclogite belonging to Lower Seve records the peak metamorphic conditions of 2.5-2.6 GPa and $650-700{ }^{\circ} \mathrm{C}$ [41]. Similar pressure-temperature (P-T) conditions of $2.5-2.7 \mathrm{GPa}$ and $680-760{ }^{\circ} \mathrm{C}$ have been obtained by thermodynamic phase equilibrium modeling from the Tjeliken garnet-phengite gneiss hosting the aforementioned eclogite [17]. The (U)HP conditions within Lower Seve were derived by Klonowska et al. [43] in the Stor Jougdan locality, where eclogite yielded $2.8-4.0 \mathrm{GPa}$ at $750-900{ }^{\circ} \mathrm{C}$ and associated garnet-pyroxenite $2.3-3.8 \mathrm{GPa}$ at $810-960^{\circ} \mathrm{C}$. The Stor Jougdan peridotite and the Tjeliken eclogite yielded Sm-Nd ages of c. $460 \mathrm{Ma}$ [16], while the Lu-Hf garnet-whole rock dating of the same eclogite yielded an age of c. $458 \mathrm{Ma}$ [17]. These ages are in line with the SIMS U-Pb zircon age of c. 459 Ma obtained from the Tjeliken gneiss [17]. In contrast, Root and Corfu [22] report a significantly younger age of zircon from the Tjeliken eclogite, yielding c. $446 \mathrm{Ma}$. The Friningen garnet peridotite (Figure 1b), which belongs to Middle Seve, records a Caledonian subduction and related equilibration at $3.1 \mathrm{GPa}$ and $810^{\circ} \mathrm{C}$ (M2 assemblage; [44]). Additionally, the similar P-T conditions of $3.0 \mathrm{GPa}$ and $800{ }^{\circ} \mathrm{C}$ were obtained from a kyanite-bearing eclogite dyke within the Friningen peridotite [42]. Collectively, the SNC in northern Jämtland and southern Västerbotten records Late Ordovician peak metamorphism of c. 465-446 Ma, depending on the geochronological method used [16,22,40]. Grimmer et al. [26] constrained the timing of exhumation, suggesting c. 430-426 Ma shearing along the Middle Seve basal thrust at mid-crustal levels, based on the white mica-plagioclase Rb-Sr isochron. Recently, the exhumation age of c. 430 Ma of the SNC in northern Jämtland was confirmed by Bender et al. [45] and interpreted as an emplacement of nappes into the lower/mid-crustal levels. The Upper Seve represents garnet-bearing mica schists interlayered with abundant lenses of amphibolite, varying from hundreds of meters to kilometers in length. 


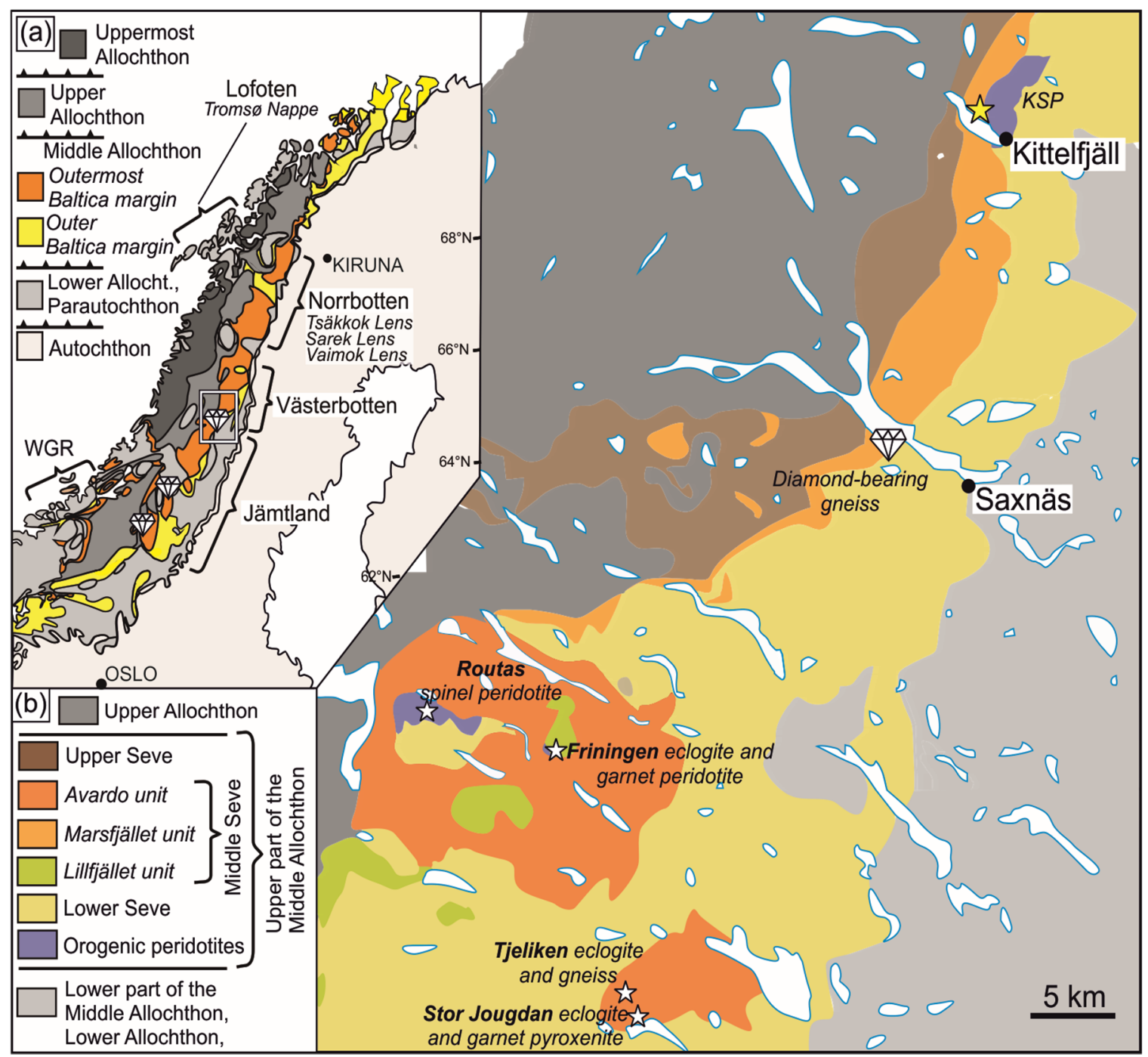

Figure 1. Geological map of the study area: (a) Simplified tectonostatigraphic map of the Scandinavian Caledonides (after Gee et al., [6]). The diamond symbols indicate localities within the Seve Nappe Complex with confirmed metamorphic microdiamonds, i.e., from south to north: Tväråklumparna [27], Åreskutan [14] and Saxnäs [14,25]. The rectangle shows the area presented on map (b). Abbreviations: Western Gneiss Region (WGR). (b) A simplified tectonostratigraphic map of the northern Jämtland/southern Västebotten area. The yellow star marks the sampling area within the high-grade Marsfjället unit.

The Marsfjället unit (Figure 1b) consists of migmatitic paragneisses and garnet amphibolites that have undergone amphibolite to granulite facies metamorphism [46,47]. However, Grimmer et al. [26] showed evidence of eclogite facies metamorphism of garnet-kyanite mica schists from the Middle Seve Nappe, recording a decompression from HP conditions of at least $1.7 \mathrm{GPa}$ at $\sim 670{ }^{\circ} \mathrm{C}$. Subsequently, a microdiamond of metamorphic origin has been reported from the kyanite-garnet-bearing Marsfjället gneiss cropping out near Saxnäs [25], showing that metasedimentary rocks of Middle Seve in Västerbotten underwent (U)HP metamorphism. The diamond has been identified within inclusions in garnet, kyanite and zircon, whereas in the west-central Jämtland localities diamonds have been found only in garnet [14,27]. Despite the lithological similarities, monazite from Saxnäs yields a significantly older Th-U-Pb age of c. $472 \mathrm{Ma}$, which is interpreted as reflecting the timing of (U)HP metamorphism [25]. In the Kittelfjäll region, the Marsfjället unit forms approximately a $4 \mathrm{~km}$ wide N-S trending belt of extensively migmatized paragneisses, hosting abundant lenses of garnet amphibolites and ultramafic rocks (Figure 1b). In the west, it is overlain by a thin sliver of 
mica schists intercalated with amphibolites. In the east, the Marsfjället unit occurs together with garnet-clinopyroxene-plagioclase-bearing Kittelfjäll amphibolites and a huge body of the Kittelfjäll spinel peridotite (KSP_Figure 1b; e.g., Clos et al. [15] and references therein). Despite the lack of reported eclogites in the studied area and precise P-T estimates of the peak metamorphic conditions, HP metamorphic conditions of Kittelfjäll paragneisses have been speculated as they share a common exhumation history with the KSP from P-T conditions of c. 1.0-2.0 GPa and $650-830{ }^{\circ} \mathrm{C}$ [15].

\section{Materials and Methods}

For this study, four rock samples were collected from the high-grade Marsfjället gneiss unit exposed to the north of Borkasjön lake, west of the Kittelfjäll village (Figure 1b). Three samples, namely MJ18-02A, MJ18-05A and MJ18-05B, represent macroscopically different subtypes of migmatitic paragneisses, whereas the sample MJ18-01 represents a garnet-bearing amphibolite hosted by migmatitic paragneiss (Figure 2). GPS coordinates of all outcrops are provided in Table S1.

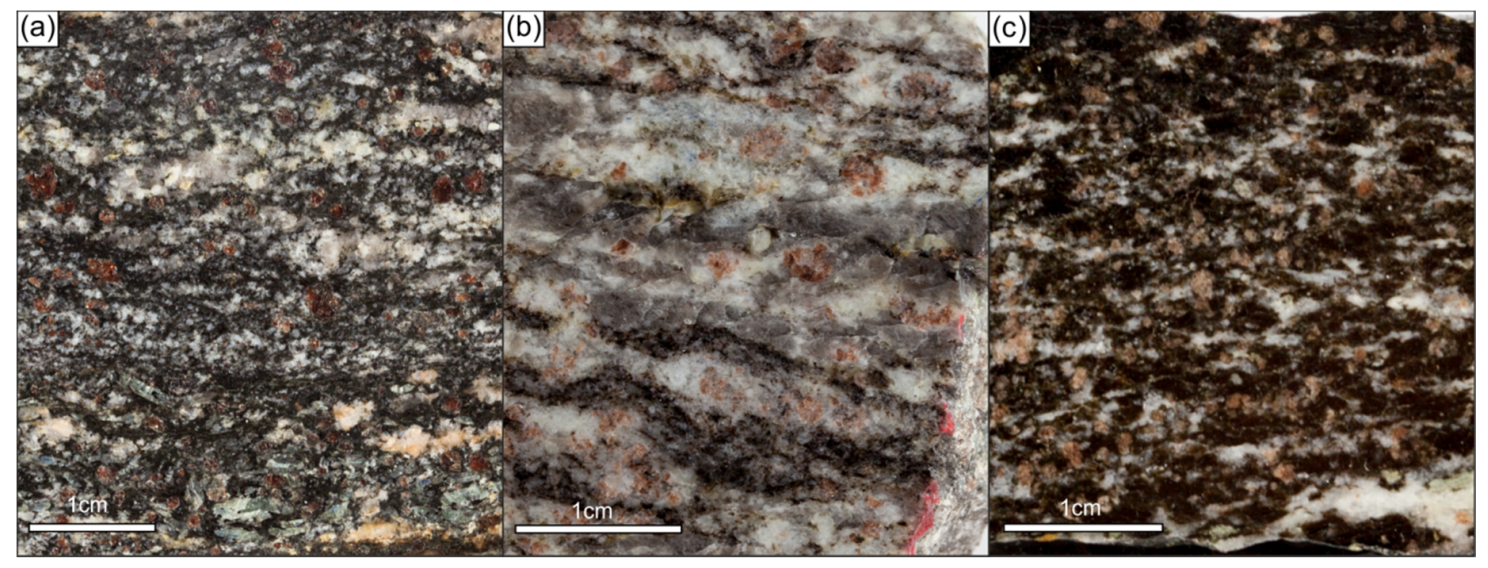

Figure 2. Photographs of the studied samples collected from the Marsfjället high-grade unit. (a) Kyanitebiotite-rich migmatitic paragneiss (sample MJ18-05A). (b) Quartz-rich migmatitic paragneiss (sample MJ18-02A). (c) Garnet amphibolite (sample MJ18-01).

The chemical composition of the minerals was obtained by wavelength dispersive spectroscopy (WDS) using a Jeol Superprobe 8230 electron microprobe (JEOL, Tokyo, Japan) at the Faculty of Geology, Geophysics and Environment Protection, AGH-University of Science and Technology (AGH-UST) in Kraków, Poland. The operating conditions were as follows: an accelerating voltage of $15 \mathrm{kV}$ and beam current of 15-20 nA for aluminosilicates. For the analyses of $\mathrm{Zr}$ in rutile, an accelerating voltage of $15 \mathrm{kV}$ and a beam current of $120 \mathrm{nA}$ were used. The counting times were $20 \mathrm{~s}$ on peaks and $10 \mathrm{~s}$ on background positions for aluminosilicates. For Zr in rutile, counting times were 150-300 s on peaks and 75-150 s on background positions. The following natural minerals and synthetic standards were used for calibration: albite $(\mathrm{Si}, \mathrm{Al}, \mathrm{Na})$, diopside $(\mathrm{Ca}, \mathrm{Mg})$, sanidine $(\mathrm{K})$, rutile $(\mathrm{Ti})$, fayalite $(\mathrm{Fe})$, rhodonite $(\mathrm{Mn})$, vanadinite $(\mathrm{V}), \mathrm{Cr}_{2} \mathrm{O}_{3}(\mathrm{Cr})$, tugtupite $(\mathrm{Cl})$, fluorite $(\mathrm{F})$, $\mathrm{YPO}_{4}(\mathrm{P})$, barite $(\mathrm{Ba})$, celestine $(\mathrm{Sr})$. Additional standard materials used for the analysis of $\mathrm{Zr}$ in rutile were: zircon $(\mathrm{Zr}), \mathrm{LiNbO}_{3}(\mathrm{Nb})$, and tantalite-(Mn) (Ta). The WDS/energy dispersive spectroscopy (EDS) chemical mapping of garnet was performed under the following conditions: accelerating voltage of $15 \mathrm{kV}$, beam current of $100 \mathrm{nA}$ and dwell time of $100 \mathrm{~ms}$. 
$\mathrm{U}-\mathrm{Pb}$ dating was performed on carefully separated zircon grains that were mounted in an epoxy mount and then polished to expose the internal parts of the crystals. The cathodoluminescence (CL) images of all mounted grains were obtained using a Hitachi SU3500 Scanning Electron Microscope at the Polish Geological Institute-National Research Institute, Warsaw Poland, to reveal the internal structure of zircon. U-Pb dating and rare earth elements (REE) analyses were completed using a $\mathrm{Nu}$ Plasma II multi-collector inductively coupled plasma mass spectrometer (MC-ICPMS) coupled to an ESI NWR193UC (Elemental Scientific Lasers, Bozeman, MT, USA) excimer based laser ablation system at the Vegacenter at the Swedish Museum of Natural History, Stockholm, Sweden. For U-Pb analyses, the $\mathrm{m} / \mathrm{z}$ (mass-to-charge ratios) corresponding to masses 202, 204, 206, 207 and 208 were measured on ion counters and those corresponding to 232, 235 and 238 were measured on Faraday collectors. Spots of 20 or $25 \mu \mathrm{m}$ in diameter were ablated at a frequency of $7 \mathrm{~Hz}$ and laser fluence of $1.7 \mathrm{~J} / \mathrm{cm}^{2}$. Helium was used as a sample carrier gas with a flow rate of $0.3 \mathrm{~L} / \mathrm{min}$, which was then mixed with $\mathrm{Ar}$ gas at a flow rate (mix gas) of $0.9 \mathrm{~L} / \mathrm{min}$. The data collection procedure included a $20 \mathrm{~s}$ ablation followed by $20 \mathrm{~s}$ washout time. The data was processed using the Iolite add-on "VizualAge" [48]. All isotope ratios were normalized to the zircon 91500 reference material with an age of $1065 \mathrm{Ma}$ [49]. The GJ-1 zircon (609 Ma; [50]; obtained age of $604 \mathrm{Ma}, 2 \mathrm{SD}=12$ ), Plešovice zircon (337 Ma; [51]; obtained age of $337 \mathrm{Ma}, 2 \mathrm{SD}=8$ ) and Temora 2 zircon (417 Ma: [52]; obtained age of $420 \mathrm{Ma}, 2 \mathrm{SD}=8$ ) were utilized as secondary standards. Age calculations and construction of concordia diagrams were prepared using the Excel extension Isoplot 4.15 [53]. All uncertainties are reported at the $2 \sigma$ level.

Rare earth elements concentrations in zircon were obtained by ablating spots of $20 \mu \mathrm{m}$ in diameter within both, zircon cores and rims of known $\mathrm{U}-\mathrm{Pb}$ age. This approach allowed us to distinguish between REE patterns displayed by Caledonian and older zircon rims, most frequently of Proterozoic age. The spots were ablated at a frequency of $8 \mathrm{~Hz}$ and fluence of $3 \mathrm{~J} / \mathrm{cm}^{2}$. The $25 \mathrm{~s}$ ablation time with $40 \mathrm{~ms}$ dwell time/isotope was followed by $20 \mathrm{~s}$ washout time. The results were quantified using the reference zircon 91500 (concentration values from Wiedenbeck et al. [54]). Plešovice [51] and GJ-I zircons [50] were used as validation material. A precision of better than 10\% RSE was achieved for most REE. Reported values of $\left[\mathrm{Eu} / \mathrm{Eu}^{*}=\mathrm{Eu}_{\mathrm{N}} / \sqrt{\left(\mathrm{Sm}_{\mathrm{N}} \times \mathrm{Gd}_{\mathrm{N}}\right)}\right]$ and $\mathrm{Lu}_{\mathrm{N}} / \mathrm{Gd}_{\mathrm{N}}$ have been calculated based on the REE concentrations normalized to $\mathrm{Cl}$ Chondrite [55].

\section{Results}

\subsection{Petrography and Mineral Chemistry}

\subsubsection{Migmatitic Paragneisses}

All three samples of the studied migmatitic paragneisses exhibit a foliation marked by the alignment of leucocratic layers and melanocratic bands. Even though paragneisses seem to show macroscopically significant differences, the mineral composition and mode of mineral occurrence are similar in all samples. The leucocratic layers are dominated by quartz, K-feldspar, plagioclase and scarce white mica, whereas the melanocratic bands are dominated by biotite and kyanite. Minor phases such as rutile, monazite, zircon, Fe-sulfides, carbonates, and ilmenite are randomly distributed within the samples. 
In the samples MJ18-05A and MJ18-05B garnet forms subhedral porphyroblasts that show almandine-rich composition varying from $\mathrm{Alm}_{60} \mathrm{Prp}_{25} \mathrm{Grs}_{12} \mathrm{Sps}_{3}$ (i.e., Almandine-Pyrope-GrossularSpessartine) in the core to $\mathrm{Alm}_{68} \operatorname{Prp}_{23} \mathrm{Grs}_{6} \mathrm{Sps}_{3}$ in the rim (Figure 3a-f; Table S2a). The garnet displays zoning marked mostly by $\mathrm{Ca}$, which decreases rimwards, whereas the opposite trend is well-marked by $\mathrm{Mg}$ and $\mathrm{Fe}$ (Figure $3 \mathrm{~b}, \mathrm{c}, \mathrm{e})$. Some grains preserve a lobate outermost rim, which is significantly enriched in Ca and simultaneously depleted in $\mathrm{Mg}$ (Figure 3b,c) and has a composition of $\mathrm{Alm}_{70} \mathrm{Prp}_{17} \mathrm{Grs}_{10} \mathrm{Sps}_{3}$. Notably, the outermost rim is preserved only along the garnet crystal faces parallel to the foliation (Figure 3a,b). The manganese content is constant throughout the entire grain (Figure 3f), except for the discontinuous outermost rim, which is slightly enriched in spessartine compared to the garnet core (Table S2a). Garnet contains scarce inclusions of quartz, rutile, zircon, and biotite (Figure 3a,g). Garnet porphyroblasts are usually enveloped by biotite and K-feldspar, which also forms grains in the garnet pressure shadows (Figure $3 \mathrm{~h}$ ) as well as large, elongated grains with a lobate boundary, most frequently associated with quartz within leucocratic bands. K-feldspar shows a minor compositional change from the core $\left(\mathrm{Or}_{90.0} \mathrm{Ab}_{9.8} \mathrm{An}_{0.2}\right)$ towards the rim $\left(\mathrm{Or}_{90.7} \mathrm{Ab}_{9.0} \mathrm{An}_{0.3}\right)$. Plagioclase forms large, rounded, and lobate grains in leucocratic bands and also shows minor compositional zoning from $\mathrm{Ab}_{71.3} \mathrm{An}_{25.9} \mathrm{Or}_{2.7}$ in the core to $\mathrm{Ab}_{74.2} \mathrm{An}_{24.7} \mathrm{Or}_{1.0}$ in the rim (Table S2b). Kyanite forms prismatic grains concentrated within dark, melanocratic bands, and shows only minor or no alteration to sillimanite at the grain boundaries. Kyanite hosts numerous inclusions of rutile, monazite, white mica, and zircon (Figure 3i,j). White mica occurs in two textural positions, either as single, partially decomposed grains enveloped by later biotite (Figure 3i) or as inclusions in kyanite. White mica grains located in the rock matrix contain 3.15-3.18 Si a.p.f.u. (atom per formula unit) compared to 3.07-3.11 Si a.p.f.u. in the inclusions in kyanite. Biotite shows a constant composition with $\mathrm{XMg}(\mathrm{Mg} / \mathrm{Mg}+\mathrm{Fe})=0.53-0.58$ (Table S2c). Rutile forms abundant single grains that are randomly distributed within the matrix or aggregates concordant to the foliation. It shows no signs of reaction to titanite, but it is commonly associated with ilmenite. Rutile has also been identified in inclusions in garnet (Figure 3g). Zircon forms rare inclusions in garnet (Figure 3g), but most frequently, it is associated with biotite, kyanite, and monazite within the melanocratic bands in the matrix (Figure 3i).

In the sample MJ18-02A garnet forms anhedral to subhedral grains containing numerous inclusions composed predominantly of quartz \pm plagioclase \pm biotite and minor zircon, rutile, sulfides, and white mica (Figure 3k). Large kyanite and plagioclase porphyroblasts are elongated concordant to the foliation defined by the alignment of K-feldspar, biotite, and white mica. Sporadic, single grains of REE-bearing carbonates can be found within the matrix (Figure 31). Plagioclase shows compositional zoning marked by increasing Na content towards the rim from $\mathrm{Ab}_{53.4} \mathrm{An}_{45.3} \mathrm{Or}_{1.2}$ to $\mathrm{Ab}_{70.9} \mathrm{An}_{27.8} \mathrm{Or}_{1.2}$. White mica forms large flakes with Si content varying from 2.99 to $3.12 \mathrm{Si}$ a.p.f.u and is partially decomposed to K-feldspar \pm biotite \pm quartz (Figure $3 \mathrm{~h}$ ). Biotite forms only small grains in the matrix with a constant composition of $\mathrm{XMg}=0.60-0.64$. Rutile forms inclusions in garnet (Figure $3 \mathrm{k}$ ) and kyanite as well as grains disseminated in the matrix. Rutile contains thin lamellae of ilmenite, but-shows no signs of replacement by titanite, despite the fact that idiomorphic titanite grains have also been found in the matrix. Monazite forms anhedral grains (up to $200 \mu \mathrm{m}$ in diameter) widespread in the matrix. Zircon is widespread within the whole sample. It has been found as inclusions in garnet and plagioclase (Figure 31) and as single grains randomly distributed in the matrix. Locally, a series of zircon grains have been identified within the outermost rim of the garnet as well as in the close vicinity of the garnet grain boundaries, preserving features of partial melting (Figure 3k). 

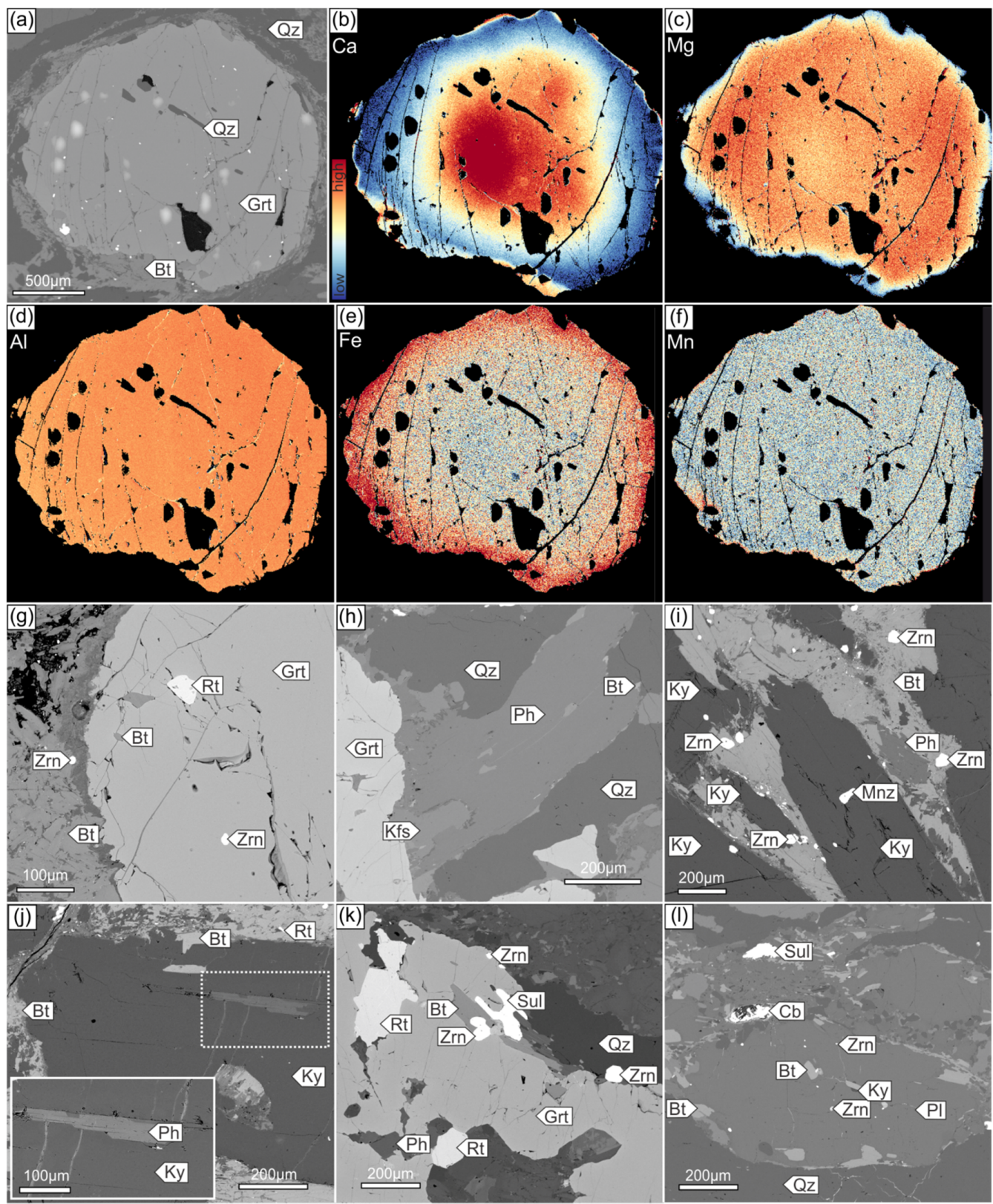

Figure 3. Back-scattered electron (BSE) and wavelength-dispersive X-ray spectrometry (WDS) maps of the rock forming minerals in migmatitic paragneisses. (a) BSE image of the garnet (MJ18-05A) presented in the WDS maps in (b-f). The bright spots on the BSE image mark the area of removed graphite coating. These areas were removed from the X-ray maps during data treatment in XMapTools v.2.3.1 [56]. WDS maps show the peak counts measured only in the garnet grain. (b) X-ray map of Ca, (c) X-ray map of Mg. (d) X-ray map of Al. (e) X-ray map of Fe. (f) X-ray map of Mn. (g) BSE image of garnet hosting inclusions of zircon and rutile (MJ18-05A). (h) A phengite grain breaking down to biotite and K-feldspar in the garnet pressure shadow (MJ18-02A). (i) Kyanite porphyroblasts enveloped by biotite and partially decomposed phengite. Note the abundant zircon and monazite grains (MJ18-05A). (j) A phengite grains hosted in kyanite porphyroblast (MJ18-05A). (k) Partially melted garnet with abundant zircon grains located at the garnet grain edge (MJ18-02A). (1) Plagioclase grain in the neosome. Note the unusually bright a REE-bearing carbonate (MJ18-02A). Mineral abbreviations: garnet (Grt), rutile $(\mathrm{Rt})$, biotite $(\mathrm{Bt})$, zircon $(\mathrm{Zr})$, quartz $(\mathrm{Qz}), \mathrm{K}$-feldspar $(\mathrm{Kfs})$, phengite $(\mathrm{Ph})$, kyanite $(\mathrm{Ky})$, monazite $(\mathrm{Mnz})$, sulfide (Sul), carbonate $(\mathrm{Cb})$, plagioclase $(\mathrm{Pl})$. 


\subsubsection{Garnet Amphibolite}

The sample MJ18-01 shows a foliation defined by parallel alignment of quartz and plagioclase aggregates and a concordant elongation of amphibole grains. Amphibole is the most abundant phase, forming large, subhedral grains. Amphibole has been identified in rare inclusions in garnet. Despite its abundance, amphibole shows a fairly uniform chemical composition encompassing pargasite and magnesio-hornblende species (Table S3a). Garnet is randomly distributed within the matrix and shows a variety of crystal shapes. It forms either subhedral grains with preserved crystal faces or anhedral grains with a highly irregular shape resembling a lobate texture (Figure 4a,g). Frequently, garnet is surrounded by irregularly shaped domains that are composed of quartz and plagioclase; additionally, in some places, garnet is replaced by biotite at the grain boundary (Figure $4 \mathrm{~h}$ ). Despite these various shapes, the vast majority of garnet grains show similar compositional differences between the core and rim. Chemical zoning within the core is well-marked by $\mathrm{Ca}$ and $\mathrm{Mg}$ distribution and changes rimward from $\mathrm{Alm}_{50} \mathrm{Grs}_{28} \operatorname{Prp}_{17} \mathrm{Sps}_{5}$ to $\mathrm{Alm}_{52} \mathrm{Grs}_{31} \operatorname{Prp}_{14} \mathrm{Sps}_{3}$ (Table S3b). The garnet rim displays the high-Ca composition of $\mathrm{Alm}_{45} \mathrm{Grs}_{41} \operatorname{Prp}_{11} \mathrm{Sps}_{3}$. Garnet seldom hosts inclusions of quartz, plagioclase, apatite, and amphibole. However, some garnet grains have an additional domain within the core that has numerous chromite inclusions (Figure $4 a-f$ ). This domain is enriched in $\mathrm{Cr}$ and $\mathrm{Ca}$ compared to the typical core domain and shows the composition of $\mathrm{Alm}_{48-45} \mathrm{Grs}_{27-22} \operatorname{Prp}_{16-14} \mathrm{Uvr}_{14-9} \mathrm{Sps}_{2} \mathrm{Adr}_{<1}$ (Figure 4b-f; Table S3b). The outer core shows typical compositional changes marked by a rimward decrease in $\mathrm{Mg}$ and an increase in Ca from $\mathrm{Alm}_{50} \mathrm{Grs}_{26} \operatorname{Prp}_{20} \mathrm{Sps}_{\sim 2} \mathrm{Uvr}_{<1} \mathrm{Ad}_{<1}$ to $\mathrm{Alm}_{50} \mathrm{Grs}_{30} \operatorname{Prp}_{16} \mathrm{Sps}_{2} \mathrm{Uvr}_{<2} \mathrm{Adr} \sim_{1}$. The rim also has a high-Ca composition of $\mathrm{Alm}_{48-44} \mathrm{Grs}_{41-35} \operatorname{Prp}_{15-12} \mathrm{Sps}_{2.4-2.1} \mathrm{Uvr}_{1.3-0.8} \mathrm{Adr}_{0.7-0.0}$. Chromite has been found only within these seldom garnet inner cores, where it forms irregular, yet rounded inclusions of uniform composition $\mathrm{Xcr}(\mathrm{Cr} / \mathrm{Cr}+\mathrm{Al})=0.71-0.73, \mathrm{Xmg}=0.02-0.07$ (Figure 4a-f; Table S3c). Chromite hosts numerous carbonate, rutile and chlorite inclusions (Figure 4i-k). The majority of these inclusions show a negative crystal shape of spinel and do not exceed $2 \mu \mathrm{m}$ in diameter. Clinopyroxene forms rare, subhedral grains in the matrix, elongated concordantly to the amphibole (Figure 4l). Clinopyroxene has a diopside composition $(\mathrm{Xmg}=0.74-0.77)$. It shows only minor compositional change at the grain boundaries manifested by enrichment in $\mathrm{Ca}$ and $\mathrm{Mg}$, coupled with depletion in Fe (Xmg = 0.79-0.82) compared to the grain interior (Table S3a). Occasionally, clinopyroxene breaks down to amphibole, forming irregular domains along the grain boundary. Zoisite is a minor phase and occurs as single matrix-located grains or forms poikiloblastic intergrowths within large quartz and plagioclase domains (Figure $4 \mathrm{~m}$ ). Plagioclase has been identified in three textural positions, i.e., (i) in inclusions in garnet, (ii) within poikiloblastic domains with quartz and zoisite, and (iii) within abundant plagioclase and quartz domains within the matrix. In all positions, plagioclase has a similar composition of $\mathrm{Ab}_{70-75} \mathrm{An}_{24-30} \mathrm{Or}_{0.5-1.3}$. Rutile forms rare, small $(<30 \mu \mathrm{m})$ grains randomly distributed within the matrix, and always replaced by titanite (Figure $4 \mathrm{n}$ ). Zircon is a minor phase that forms rare, solitary grains most frequently found in the vicinity of quartz and plagioclase patches surrounding garnet (Figure $4 \mathrm{~g}$ ) or associated with titanite (Figure $4 \mathrm{n}$ ). 


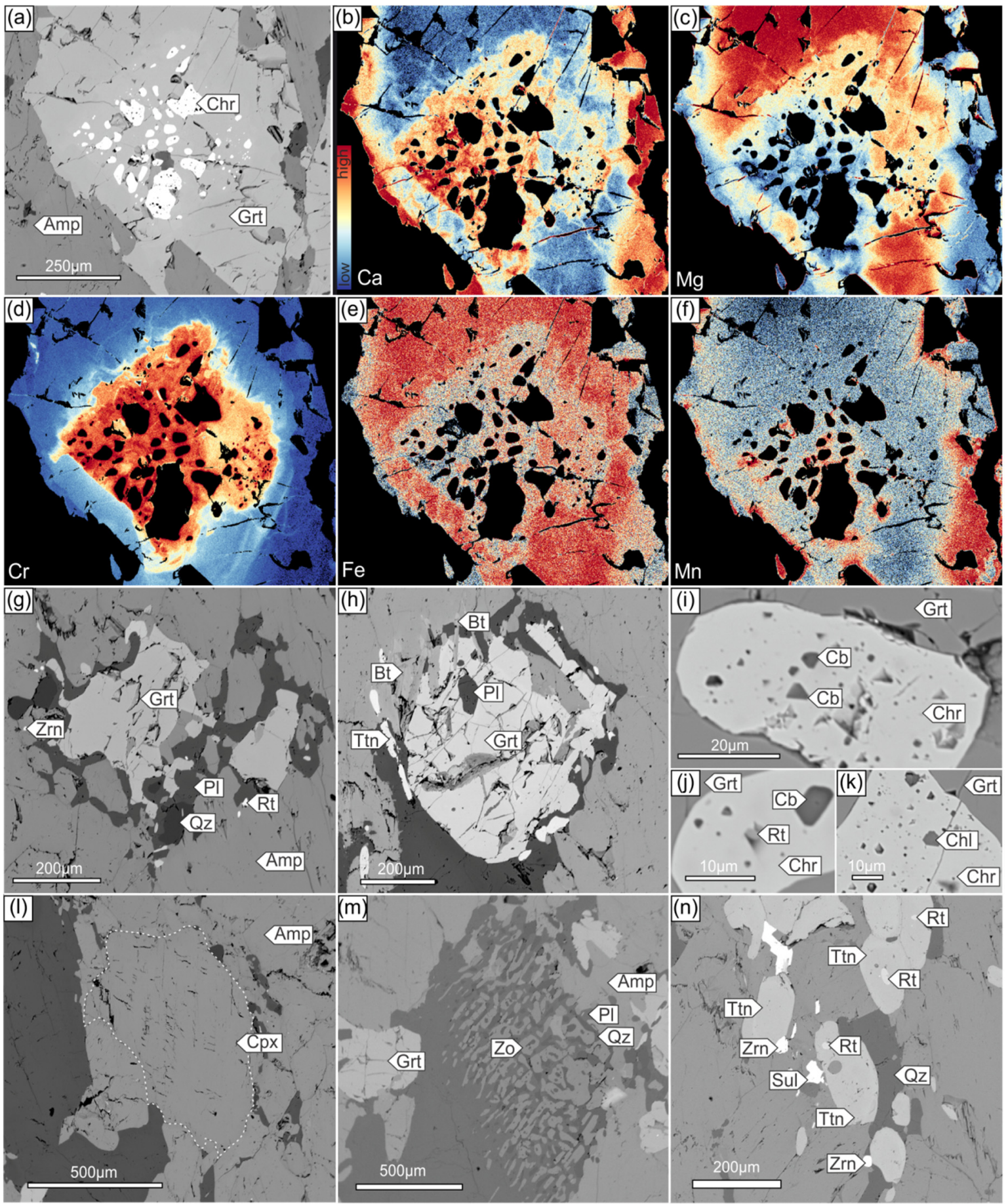

Figure 4. Back-scattered electron (BSE) and wavelength-dispersive X-ray spectrometry (WDS) maps of the rock forming minerals in garnet amphibolite (MJ18-01). (a) BSE image of the garnet presented in the WDS maps in (b-f). WDS maps show the peak counts measured only in the garnet. (b) X-ray map of Ca, (c) X-ray map of Mg. (d) X-ray map of Cr. (e) X-ray map of Fe. (f) X-ray map of Mn. (g) BSE image of partially melted garnet with a lobate grain edge. (h) Garnet grain partially replaced by biotite. (i) Chromite inclusion in garnet hosting numerous inclusions of carbonates. (j) Chromite inclusion with rutile inclusion. (k) Chromite inclusion hosting a chlorite inclusion. (1) Clinopyroxene of diopside composition preserved in the matrix. The white dotted line outlines the boundary of the Cpx grain. (m) Poikiloblastic intergrowth of zoisite and plagioclase. (n) Scarce rutile grains replaced by titanite. Note the abundant zircon in the vicinity of titanite. Mineral abbreviations: garnet (Grt), zircon ( $\mathrm{Zr}$ ), plagioclase (Pl), quartz (Qz), amphibole (Amp), biotite (Bt), titanite (Ttn), carbonate $(\mathrm{Cb})$, chromite (Chr), chlorite (Chl), clinopyroxene (Cpx), zoisite (Zo), sulfide (Sul). 


\subsection{Zr-in-Rutile Thermometry}

The temperature has been estimated using the pressure-dependent calibration of the $\mathrm{Zr}$-in-rutile thermometer by Tomkins et al. [57]. Rutile from the sample MJ18-01 shows consistent, relatively high concentrations of $\mathrm{Zr}=688-925 \mathrm{ppm}$, which result in a temperature range of $774-821^{\circ} \mathrm{C}$ (at the fixed pressure of $25 \mathrm{kbar}$; Figure 5; Table S4). A single, identified inclusion of rutile hosted by chromite appeared to be too small to avoid contamination during analysis and to obtain a reliable result. In the sample MJ18-02A, Zr content in rutile inclusions varies from 614 to $710 \mathrm{ppm}$, while the matrix rutile contains between 296 and 561 ppm of Zr. Rutile in the sample MJ18-05A shows a similar, yet more visible relationship. Rutile inclusions contain 392-444 ppm of $\mathrm{Zr}$, whereas $\mathrm{Zr}$ in the matrix rutile varies over a 185-244 ppm range. The rutile inclusions yielded $\mathrm{T}>738^{\circ} \mathrm{C}$ and $>780^{\circ} \mathrm{C}$ (at a fixed pressure of $25 \mathrm{kbar}$ ) in the samples MJ18-05A and MJ18-02A, respectively. The matrix rutile displays a $\mathrm{T}<655$ ${ }^{\circ} \mathrm{C}$ and $<726{ }^{\circ} \mathrm{C}$ in the samples MJ18-05A and MJ18-02A, respectively (at a fixed pressure of $15 \mathrm{kbar}$; Figure 5; Table S4).

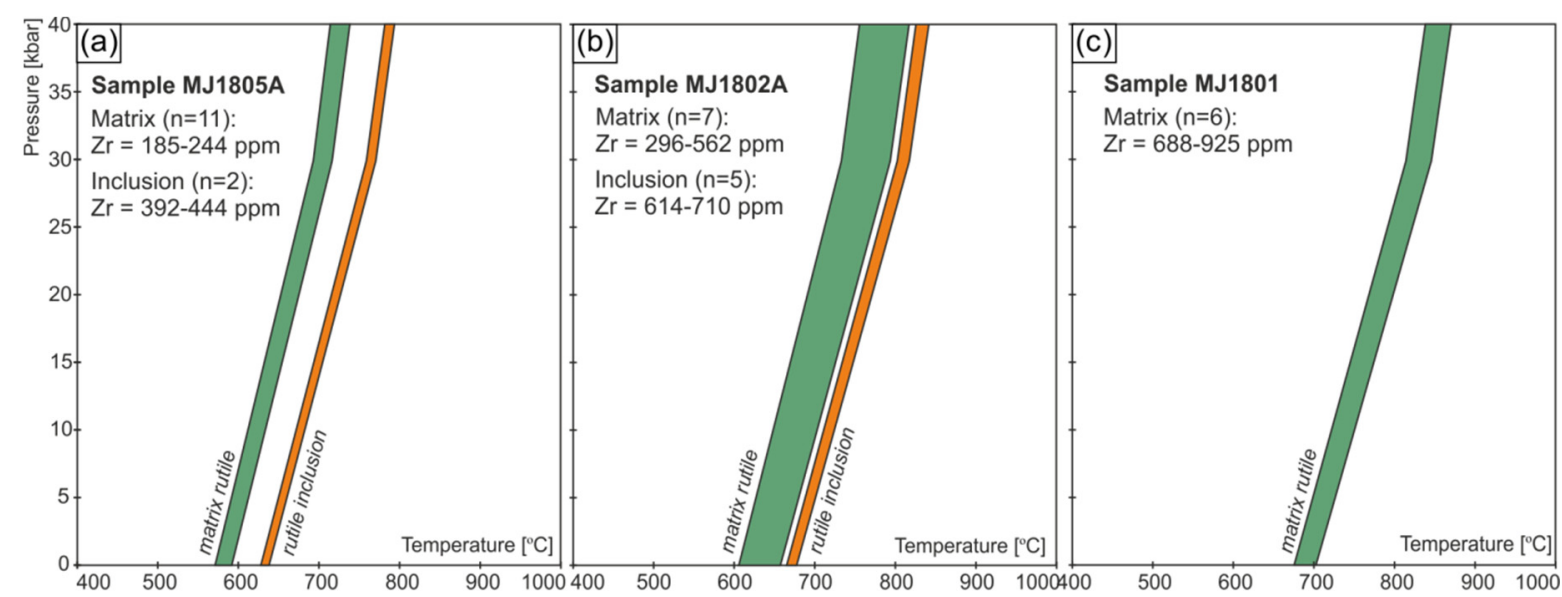

Figure 5. P-T diagrams showing the results of Zr-in-rutile geothemometry for a given textural types of rutile. Green fields show the results for matrix rutile, whereas the orange fields represent temperature range calculated for rutile inclusions. (a) Sample MJ18-05A: migmatitic paragneiss. (b) Sample MJ18-02A: migmatitic paragneiss. (c) Sample MJ18-01: garnet amphibolite.

\subsection{Zircon $\mathrm{U}-\mathrm{Pb}$ Dating}

Zircon separated from migmatitic paragneisses occurs as sub-idomorphic, nearly isometric or elongated grains, most frequently not exceeding $200 \mu \mathrm{m}$ in length. The CL imaging revealed the complex internal structure of the studied grains, with cores enveloped by zircon overgrowths (Figure 6). The zircon cores most frequently preserve oscillatory and sector zoning, and likely represent former detrital grains of the protolith. The overgrowths are significantly darker in CL compared to the cores. The majority of the overgrowths are homogenous with no visible internal structure and only some show subtle concentric and cloudy zoning (e.g., the first grain in section MJ18-02A in Figure 6).

$\mathrm{U}-\mathrm{Pb}$ isotope analyses of zircon cores and non-Caledonian zircon rims from the migmatitic paragneisses (MJ18-05A, $n=37$; MJ18-05B, $n=36$; MJ18-02A, $n=21$ ) reveal a wide age spectrum from Paleo- and Mesoproterozoic to early Paleozoic, reflecting the heterogeneous provenance of the sediment protolith (Figure $7 \mathrm{a}, \mathrm{c}, \mathrm{e}$ ). The vast majority of the zircon core and non-Caledonian zircon rim analyses are moderately discordant (Table S5); however, in all samples, concordant analyses (less than $10 \%$ discordance) of Meso-to-Neoproterozoic age yield clusters between c. 1100-900 Ma, and between c. 1450-1350 Ma in samples MJ18-05A and MJ18-05B (Figure 7). The obtained results do not differ from previously published provenance studies of other Seve Nappe Complex rocks $[58,59]$. 


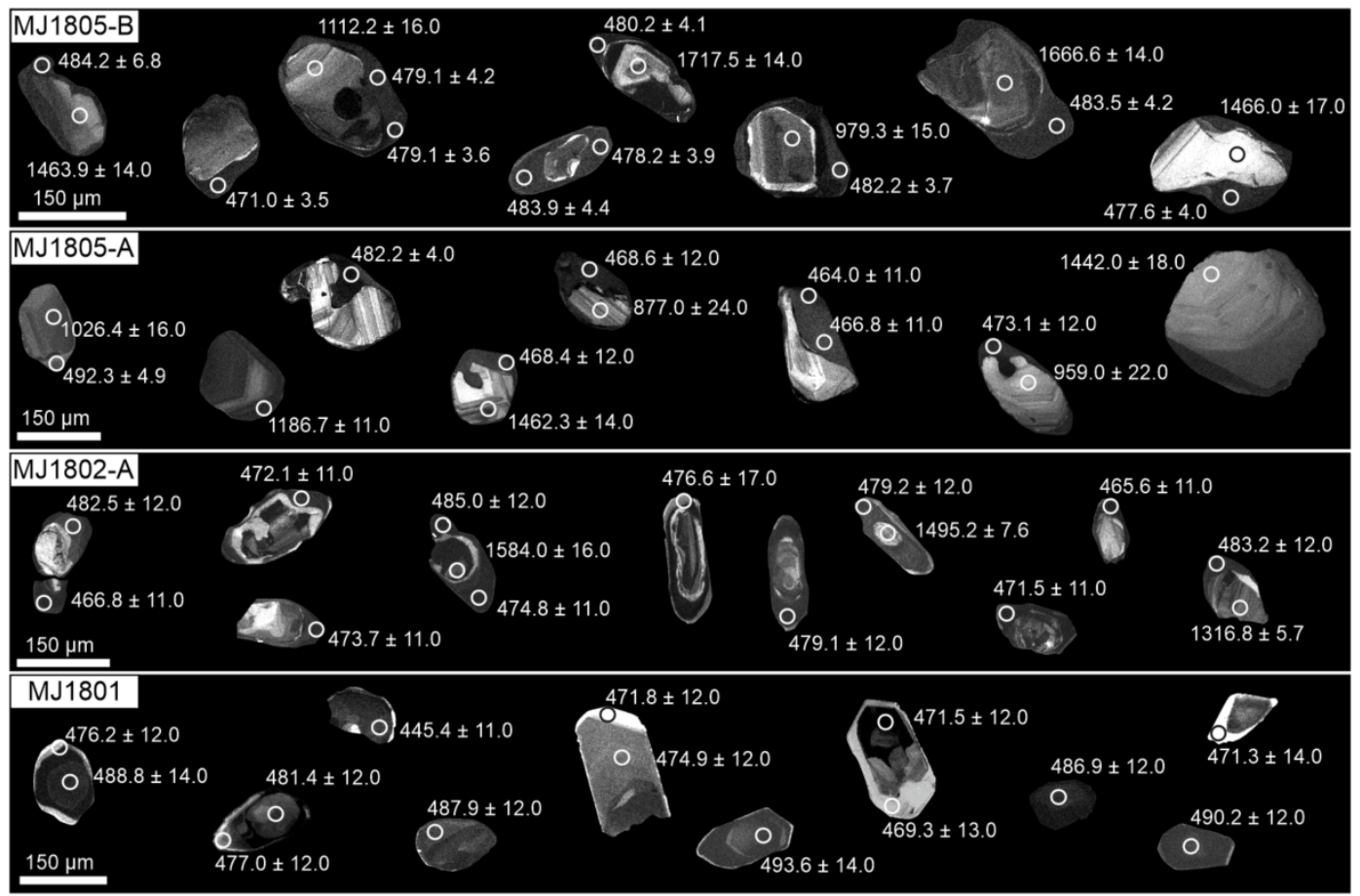

Figure 6. Cathodoluminescence (CL) images of representative zircon grains displaying a variety of microtextures. The white circles mark the analytical spots with obtained ${ }^{206} \mathrm{~Pb} /{ }^{238} \mathrm{U}$ ages (for Caledonian ages) and ${ }^{207} \mathrm{~Pb} / 206 \mathrm{~Pb}$ for ages $>900 \mathrm{Ma}$.

In the sample MJ18-05A, 25 zircon rims have been analysed. Only nine of the analysed rims are Caledonian. One discordant analysis was excluded from age calculation (Table S5a). Eight spot analyses representing Caledonian age cluster yield a lower intercept age of $474.8 \pm 5.8 \mathrm{Ma}(n=8$, MSWD = 1.9; Figure 7b; Table S5a) with the ${ }^{206} \mathrm{~Pb} /{ }^{238} \mathrm{U}$ ages ranging from $493.1 \pm 13$ to $464.0 \pm 11 \mathrm{Ma}$. Within the cluster, the subgroup of four concordant dates gives a concordia age of $469.0 \pm 4.5 \mathrm{Ma}(n=4$, MSWD $=0.97$; Figure $7 \mathrm{~b}$ ).

Twenty-six zircon rims have been analysed in the sample MJ18-05B. Thirteen of the analysed rims are Caledonian. Two discordant analyses (above 3\% discordance) were excluded from age calculation (Table S5b). Eleven spot analyses form a close group yielding a lower intercept at $479.5 \pm 2.7 \mathrm{Ma}(n=$ 11 , MSWD = 1.19; Figure 7d), with the ${ }^{206} \mathrm{~Pb} /{ }^{238} \mathrm{U}$ ages varying over a range of $483.9 \pm 4-477.6 \pm 4 \mathrm{Ma}$. However, it was impossible to calculate concordia age for this group.

In the sample MJ18-02A, 50 zircon rims have been analysed. Out of these rims, 37 are Caledonian, while five discordant analyses were excluded from age calculation (Table S5c). The remaining 32 Caledonian analyses yield a lower intercept age of $473.0 \pm 4.9 \mathrm{Ma}$ (MSWD = 1.1; Figure 7f; Table S5c) with the ${ }^{206} \mathrm{~Pb} /{ }^{238} \mathrm{U}$ ages ranging from $492.0 \pm 32$ to $462.4 \pm 11 \mathrm{Ma}$.

The majority of the zircon grains from the garnet amphibolite MJ18-01 show well-defined concentric zoning within the cores that are overgrown by CL-bright thin rims. Nevertheless, some of the analysed grains are much darker in CL and show no internal zoning (Figure 6). Twelve zircon cores, 10 zircon rims and five homogenous grains have been analysed. Only three discordant (above 3\% discordance) analyses were excluded from age calculation (Table S5d). Zircon cores and rims, as well as the homogenous grains, yielded a wide group of Caledonian dates with a total span of $>40 \mathrm{Ma}$ (Figure $7 \mathrm{~g}$ ). The whole Caledonian cluster of dates yields a lower intercept age of $474.8 \pm 9.0 \mathrm{Ma}$ $\left(\mathrm{n}=22\right.$, MSWD $=0.72$; Figure 7h), but the zircon rims show a span of ${ }^{206} \mathrm{~Pb} /{ }^{238} \mathrm{U}$ dates from $501.0 \pm 17$ to $464.8 \pm 14 \mathrm{Ma}$ (Figure $7 \mathrm{~h}$; Table S5d). The subset of concordant analyses plotted a concordia age of $471.7 \pm 3.4 \mathrm{Ma}(\mathrm{n}=8, \mathrm{MSWD}=0.039$; Figure $7 \mathrm{~h})$. The two single concordant dates stand out from the 
Caledonian U-Pb dataset, i.e., the $646 \pm 25 \mathrm{Ma}$ and $445 \pm 11 \mathrm{Ma}$ dates (Figure 7g). These outliers were not included in the age calculations.
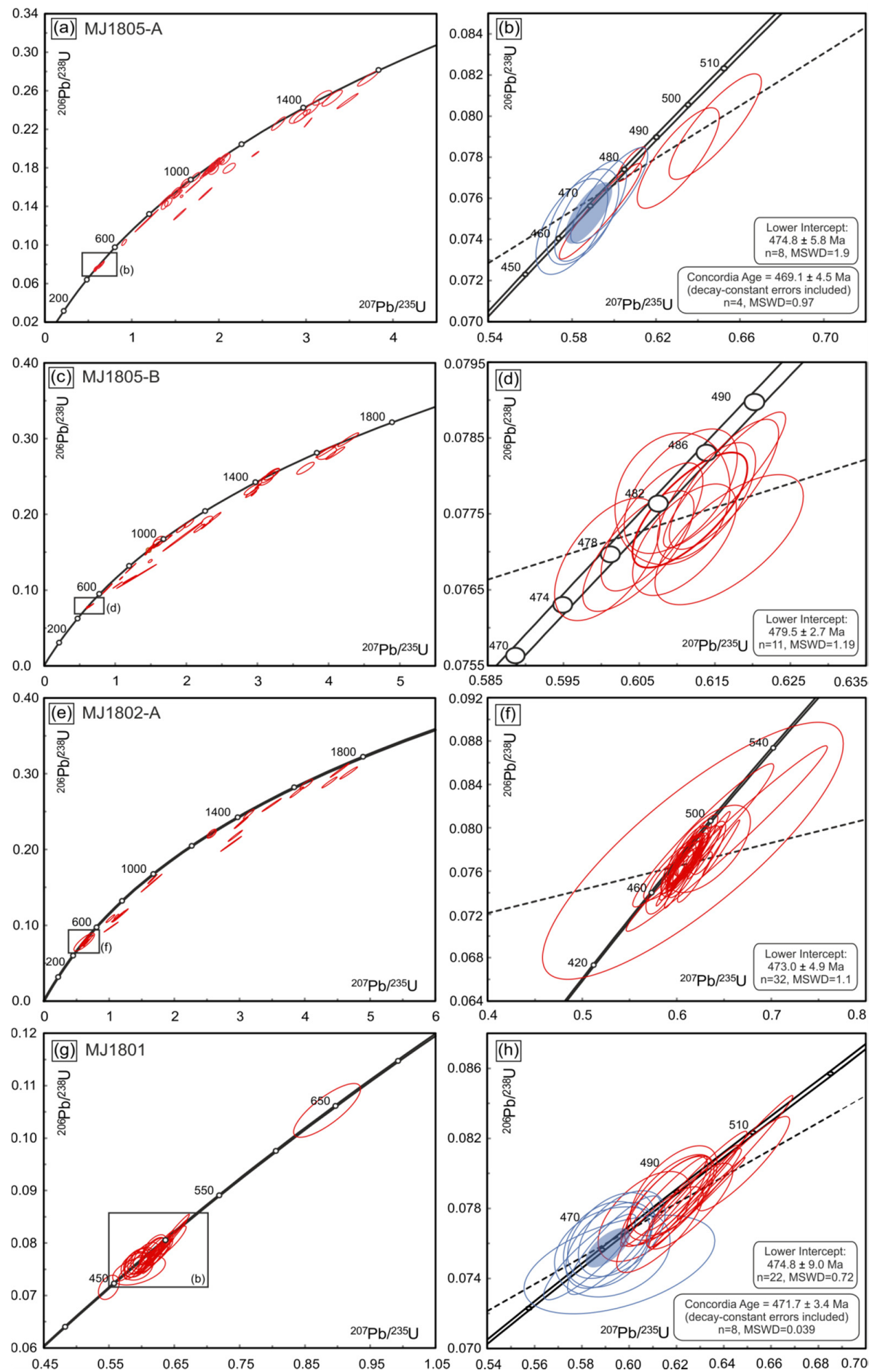

Figure 7. Concordia diagrams of zircon U-Pb analyses. (a) All analyses from sample MJ18-05A. (b) Caledonian age cluster from sample MJ18-05A. The lower intercept calculated for the whole cluster, concordia age calculated for the analyses marked by blue circle. (c) All analyses from sample MJ18-05B. (d) Caledonian age cluster from sample MJ18-05B. (e) All analyses from sample MJ18-02A. (f) Caledonian age cluster from sample MJ18-02A. (g) All analyses from sample MJ18-01. (h) Caledonian age cluster from sample MJ18-01. The lower intercept was calculated for the whole cluster, the concordia age was calculated for the analyses marked by blue circle. 


\subsection{Trace Element Chemistry of Zircon}

The zircon from migmatitic paragneisses preserves distinctive, apparently detrital, cores which display broadly similar REE patterns (Figure 8a-c). The studied cores show significant enrichment in heavy rare earth elements (HREE, average $\mathrm{Lu}_{\mathrm{N}} / \mathrm{Gd}_{\mathrm{N}}=21.37$ ). Light rare earth elements (LREE) concentrations are commonly below the detection limit (Table S6). In some of the studied grains, even though measured LREE values were above the detection limit, the analyses with errors exceeding $50 \%$ were not plotted and excluded from further discussion and interpretation. A pronounced negative $\mathrm{Eu}$ anomaly $\left[\mathrm{Eu} / \mathrm{Eu}^{*}=\mathrm{Eu}_{\mathrm{N}} / \sqrt{\left(\mathrm{Sm}_{\mathrm{N}} \times \mathrm{Gd}_{\mathrm{N}}\right)}\right]$ is well marked in all cores, with average values of Eu/Eu* $=0.29(n=10 ; \mathrm{MJ} 18-05 \mathrm{~A}), 0.28(n=7 ; \mathrm{MJ} 18-05 \mathrm{~B})$ and $0.14(n=9 ; \mathrm{MJ} 18-02 \mathrm{~A})$.
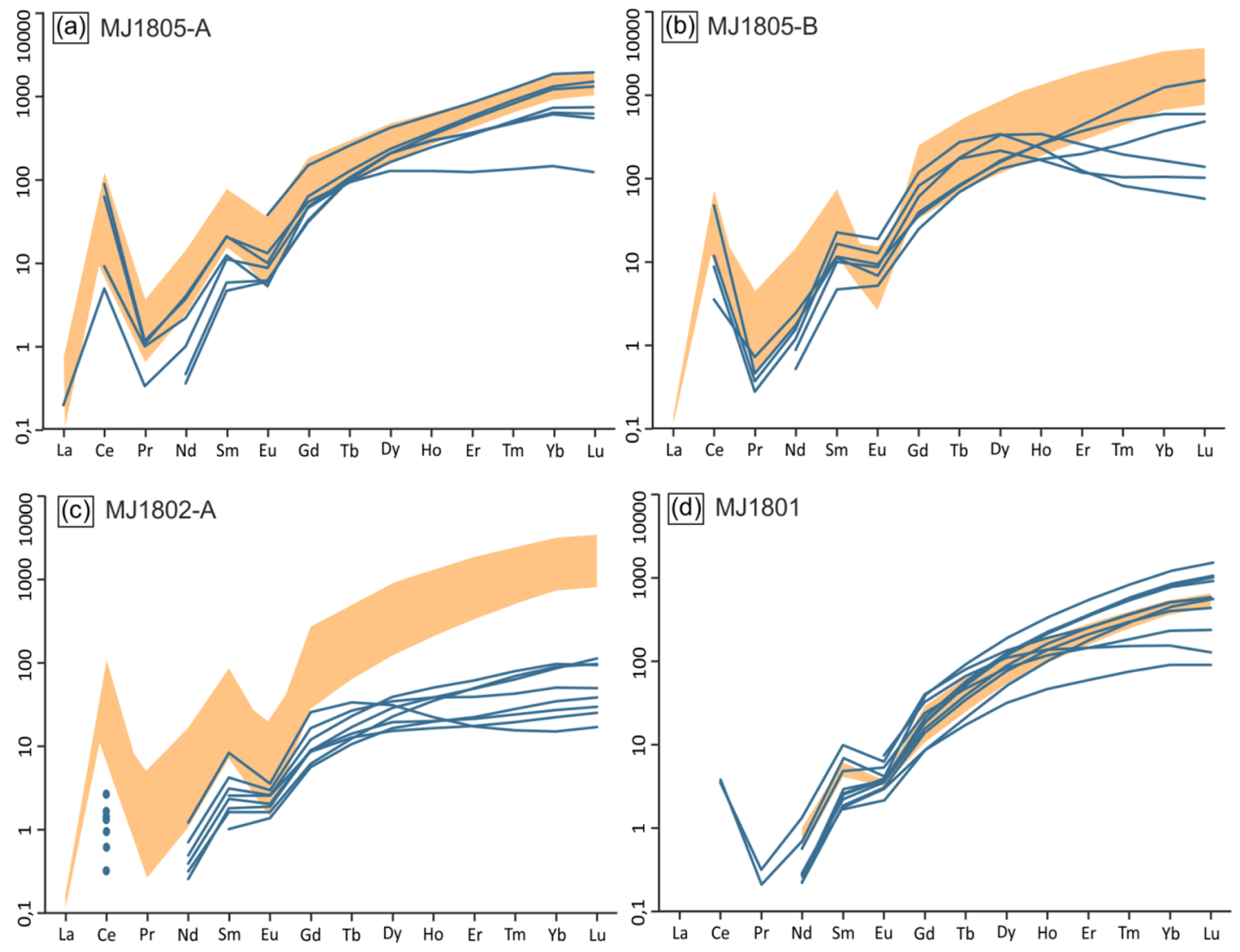

Figure 8. Chondrite-normalized REE patterns in zircon. Orange and blue lines represent zircon cores and rims, respectively. (a) Sample MJ18-05A: migmatitic paragneiss. (b) Sample MJ18-05B: migmatitic paragneiss. (c) Sample MJ18-02A: migmatitic paragneiss. (d) Sample MJ18-01: garnet amphibolite.

Caledonian zircon rims from the samples MJ18-05A and MJ18-05B display two different REE patterns (Figure 8a,b); some of the studied rims mimic the REE pattern of the cores, while others differ in HREE content and HREE to MREE ratios. In the sample MJ18-05A, the rims exhibit a rising trend in $\mathrm{HREE}$ with $\mathrm{Lu}_{\mathrm{N}} / \mathrm{Gd}_{\mathrm{N}}$ ratios range from 13.6 to 28.1, except one analysis showing a flat $\mathrm{HREE}$ pattern $\left(\mathrm{Lu}_{\mathrm{N}} / \mathrm{Gd}_{\mathrm{N}}=2.6\right.$; Figure $\left.8 \mathrm{a}\right)$. In the sample MJ18-05B, part of the analysis shows a constant increase in $\mathrm{HREE}$ with $\mathrm{Lu}_{\mathrm{N}} / \mathrm{Gd}_{\mathrm{N}}$ ratio range from 16.4 to 38.7, whereas the other part shows a relative enrichment in MREE ( $\mathrm{Gd}, \mathrm{Tb}$ and $\mathrm{Dy}$ ) followed by negative slope towards $\mathrm{Lu}$, with $\mathrm{Lu}_{\mathrm{N}} / \mathrm{Gd}_{\mathrm{N}}$ ranging from 0.5 to 2.3, but Lu/Dy $<<1$ (Figure 8b). In both MJ18-05A and MJ18-05B samples, the zircon rims display significantly less pronounced negative $\mathrm{Eu}$ anomalies than the cores, with average values of $\mathrm{Eu} / \mathrm{Eu}^{*}=0.37(n=6)$ and $\mathrm{Eu} / \mathrm{Eu}^{*}=0.39(n=9)$ respectively (Table S6a,b).

The zircon rims from MJ18-02A paragneiss exhibit the lowest REE concentrations of all studied zircons and slightly less pronounced negative Eu anomalies with an average value of $\mathrm{Eu} / \mathrm{Eu}^{*}=0.45$ 
( $n=8$; Table S6c; Figure 8c). The HREE/MREE ratios are characterized by a nearly flat pattern with $\mathrm{Lu}_{\mathrm{N}} / \mathrm{Gd}_{\mathrm{N}}=2.90-15.61$ (Figure 8c). Only one analysed rim shows a different trend marked by a high content of $\mathrm{Gd}$ and a subsequent decrease towards $\mathrm{Lu}\left(\mathrm{Lu}_{\mathrm{N}} / \mathrm{Gd}_{\mathrm{N}}=0.65\right)$. Additionally, the same analysis shows the strongest $\mathrm{Eu}$ anomaly of $\mathrm{Eu} / \mathrm{Eu}^{*}=0.24$.

Despite the CL-visible textural boundary between the cores and rims of zircons from the garnet amphibolite (MJ18-01), there are no differences between their REE patterns (Figure 8d). The zircon rims, represented by three analyses, show a negative $\mathrm{Eu}$ anomaly of $\mathrm{Eu} / \mathrm{Eu}^{*}=0.28-0.34$, indistinctive to the zircon cores with values varying over a broad range of $\mathrm{Eu} / \mathrm{Eu}^{*}=0.25-0.76$ (Table S6d). The vast majority of analyses show the same trend marked by increasing HREE content; however, the $\mathrm{Lu}_{\mathrm{N}} / \mathrm{Gd}_{\mathrm{N}}$ ratio varies over a range of 10.04-65.13. Noteworthy, one rim analysis shows the flat HREE pattern $\left(\mathrm{Lu}_{\mathrm{N}} / \mathrm{Gd}_{\mathrm{N}}=3.96\right)$.

\section{Discussion}

\subsection{Metamorphic Evolution}

Notwithstanding the pervasive migmatization of the studied rocks, remnants of the peak pressure mineral assemblage have been preserved in both the paragneisses and the amphibolite. In the paragneisses, garnet, kyanite, quartz, phengite, rutile and zircon represent the assemblage stable at HP conditions. The presence of the latter two as inclusions within the outer part of the garnet core implies that they were stable during the prograde and near-peak part of the P-T path. Even though the white mica has been identified in inclusions either in the kyanite (Figure 3j; sample MJ18-05A and -B) or in the garnet (Figure 3k; sample MJ18-02A), only some of the mica grains preserve phengitic composition (>3.1 Si a.p.f.u.). Most of the partially decomposed grains, especially those that break down to K-feldspar, have a muscovite composition. The garnet preserves a prograde chemical zoning marked by decreasing grossular towards the rim. However, the flat spessartine profile throughout the garnet grain suggests homogenization of the primary garnet composition in granulite facies. The outermost lobate rim of garnet grains displaying a sharp increase in Ca and Fe content (Figure 3b,e) was interpreted as a product of melt crystallization during the partial melting of metapelites [60]. The interaction with melt prompted a back-diffusion of $\mathrm{Mn}$, leading to enrichment in spessartine content at the grain boundary (Figure 3f). The outermost rim is exceptionally well marked at the planes parallel to the foliation, where garnet is in contact with a neosome (Figure 3a). This observation additionally attests to the modification of garnet edge during melting. As discussed above, partial melting and significant modification of the primary composition of minerals from the peak pressure assemblage calls into question applicability of conventional geothermobarometry methods to estimate the P-T conditions of the peak pressure stage. However, rutile inclusions in garnet, once entrapped, are believed to retain the recorded temperature expressed by $\mathrm{Zr}$ content [57]. Since the rutile inclusions are not recrystallized, we do interpret the obtained temperatures as indicative of the near-peak temperatures as $>738{ }^{\circ} \mathrm{C}$ and $>780^{\circ} \mathrm{C}$ (at the pressure of $2.5 \mathrm{GPa}$ ) in the samples MJ18-05A and MJ18-02A, respectively (Figure 5a,b).

The peak pressure stage, which presumably took place at (U)HP conditions based on the estimations provided by Petrík et al., [25] from the nearby Saxnäs locality, was followed by an extensive granulite facies overprint and related migmatization. The latter caused formation of the garnet (outermost rim)-K-feldspar-plagioclase-quartz-biotite-ilmenite-titanite-zircon assemblage. Based on the textural observations, it is inferred that partial melting was driven by coupled processes of decompression and dehydration. The dehydration melting has been deduced from the white mica breakdown commonly observed in garnet pressure shadows, where mica is replaced by K-feldspar accompanied by biotite and quartz (Figure 3h). Plagioclase is a common phase involved in a melt-generating reaction during white mica breakdown in metapelites at conditions within the kyanite stability field [61-63]. Plagioclase is unstable at $(\mathrm{U}) \mathrm{HP}$ conditions, hence the occurrence of its large porphyroblasts, which suggests formation at the earliest stages of decompression melting. This interpretation is favoured by the observation of increased content of $\mathrm{Na}$ at the plagioclase grain boundary in contact with a melted 
neosome (Figure 31), implying that the composition of the plagioclase core was not in equilibrium with the partial melt. The direct evidence for decompression at relatively high-temperature conditions is provided by the exsolution of ilmenite from the matrix rutile, which designates a decompression to pressures below c. 1.4 GPa (Meinhold [64] and references therein). Further recrystallization to titanite implies a continuous decrease in temperature and represents the late stage of exhumation and cooling down to amphibolite facies. Additionally, the matrix rutile records temperatures of $<655^{\circ} \mathrm{C}$ and $<726{ }^{\circ} \mathrm{C}$ (assuming the pressure of $1.5 \mathrm{GPa}$; Figure 5a,b) in the samples MJ18-05A and MJ18-02A, respectively. These temperatures are noticeably lower than the calculated temperatures for rutile occurring as inclusions. This also advocates for re-equilibration at lower pressure.

In the garnet amphibolite, the scarcely preserved high-Cr garnet core, chromite and rutile are the only remnants of possible (U)HP assemblage representing pre-melting stage (Figure 4). The observed assemblage of garnet rim-diopside-plagioclase is inferred to represent an early stage of exhumation under granulite facies conditions, which was followed by extensive recrystallization leading to the formation of amphibole-titanite-biotite-zoisite under amphibolite facies conditions. The lobate garnet grain boundaries (Figure $4 \mathrm{~g}$ ) enveloped by plagioclase-quartz aggregates attest the presence of melt during the exhumation, presumably simultaneously with the development of weak foliation. The garnet amphibolite shows striking resemblance with strongly retrogressed eclogites reported from the Sippmikk creek - the type local to the Middle Seve eclogites in northern Jämtland $[38,39,65]$. The assemblage of diopside-brown-green amphibole of pargasite composition- plagioclase \pm biotite \pm titanite has been attributed to upper amphibolite facies recrystallization of eclogite [39]. Additionally, since scarce spinel has also been reported in the Seve eclogites as a product of eclogite facies assemblage recrystallization during the granulite facies overprint [66], the same process can be expected to be recorded by the Kittelfjäll amphibolite. However, the spinel observed in (retro) eclogites in Jämtland displays magnetite composition, whereas the spinel inclusions in garnet reported in this study show, unusually for eclogite, chromite composition. The presence of chromite and associated $\mathrm{Cr}$-enriched garnet is typically attributed to crystallization from an (ultra) mafic silicate melt at mantle conditions [67]. Notably, the abundant chromite inclusions hosted by garnet have also been reported from the garnet pyroxenite vein at Stor Jougdan, closely associated with eclogite and peridotite (SNC; [43]. These garnet pyroxenites crop out approximately $50 \mathrm{~km}$ south of Kittelfjäll and reveal P-T conditions of c. 2.3-3.8 GPa and 810-960 ${ }^{\circ} \mathrm{C}$ [43]. Additionally, the two generations of chromite have been described from the Kittelfjäll peridotite (Figure $1 \mathrm{~b}$ ) and are attributed to both the pre-Caledonian phase M1 (>870 $\left.{ }^{\circ} \mathrm{C}, 1-4 \mathrm{GPa}\right)$ and the Caledonian phase M2 (650-830 ${ }^{\circ} \mathrm{C}, 1-2 \mathrm{GPa}$; [15]). The M2-chromite reported by Clos et al., [15] is intergrown with and enveloped by high-Cr chlorite, which is inferred to represent the recrystallization at the presence of fluid [68]. However, with the chromite from the sample MJ18-01 shows $X_{c r}=0.71-0.73$, which correlates with the composition of the M2-chromite reported from the Kittelfjäll peridotite (i.e., $X_{c r}=0.73-0.84 ;$ [15]), the measured $\mathrm{Xmg}<0.07$ is much below values of $\mathrm{Xmg}=0.28-0.41$ reported for chromite from the peridotite [15]. Nevertheless, the similar chromite mode of occurrence, as well as chlorite inclusions, show the resemblance between the studied amphibolite and the Kittelfjäll peridotite. According to the discrimination criteria between garnet pyroxenite and eclogite proposed by Medaris et al. [69], the bulk composition of the garnet amphibolite (sample MJ18-01) with $\mathrm{Na}_{2} \mathrm{O}$ exceeding $0.75 \mathrm{wt} . \%$, and $\mathrm{Ni}$ and $\mathrm{Cr}$ below 400 and 1500 ppm, respectively, suggests an eclogitic origin (Table S1). The content of $\mathrm{Na}_{2} \mathrm{O}$ above the values expected for the garnet pyroxenites should be indicative of a former presence of omphacite before the partial melting event took place.

We propose here a possible scenario in which the garnet amphibolite may have originated from a similar protolith as the Kittelfjäll peridotite, which was incorporated into the Seve metasediments during ongoing subduction. Hence, the high-Cr garnet would reflect the high-Cr composition of the chlorite precursor enveloping chromite grains instead of a deep-mantle crystallization of ultramafic melt. The metamafic rocks from SNC are widely considered to be metamorphosed basalts, dolerites and gabbros $[4,19,65,70]$ representing products of late Neoproterozoic magmatic activity related to the 
opening of the Iapetus ocean $[3,4]$. However, the close association of eclogites, garnet-pyroxenites and peridotites hosted in the Seve metasediments is well-documented [42,43], and observations from the Kittelfjäll amphibolite call into careful reconsideration of the source of at least some garnet amphibolites throughout the SNC. Nevertheless, unravelling such complex origin of the garnet amphibolite protolith is beyond the scope of this paper, yet outlines an attractive future research target.

\subsection{U-Pb Ages and Conditions of Zircon Formation}

Zircon is known to crystallize in a broad P-T space encompassing low grade [71] to (U)HP and UHT conditions [72,73], but its affiliation to a given mineral assemblage based solely on textural observations can be a challenging task. However, coupling zircon U-Pb isotopic analyses with detailed textural observations and REE signatures can help to decipher zircon growth history during a metamorphic cycle.

The zircon cores from paragneisses display a multiplicity of internal textures (Figure 6). The textural heterogeneity, variable $\mathrm{Eu}$ anomalies and broad $\mathrm{U}-\mathrm{Pb}$ age spectra reflect a heterogeneous source of zircon in the protolith. The zircon rims define the idio- and subidiomorphic shape of grains. They also show significantly lower luminescence than the cores, which is typical for metamorphic zircon [74]. Faint concentric and cloudy zoning, observed in some of the studied rims, suggests the presence of melt during zircon growth or its precipitation from a fluid [75,76]. Additionally, some of the zircon rims form lobate-shaped intergrowths with cores, which may advocate for the replacement of cores by the dissolution-reprecipitation process (Figure 6 ; $[77,78]$ ). Thus, the partial corrosion of the older cores possibly provided an excess in $\mathrm{Zr}$ for new zircon growth [79]. The flat and even negative slope of the M-HREE pattern observed in several zircon rims (Figure 8) likely reflects the growth of zircon within the stability field of garnet, which is responsible for HREE fractionation (e.g., Kohn [80] and references therein). The other zircon rims display a positive slope of HREE, mimicking zircon cores' REE patterns, which is especially well-pronounced in the samples MJ18-05A and MJ18-05B (Figure $8 \mathrm{a}, \mathrm{b}$ ). Such patterns may be interpreted as an effect of the zircon growth during the partial dissolution of the garnet, resulting in HREE release to the system or the growth of new zirconat the expense of zircon cores, thus retaining the zircon core REE pattern. Such a broad variation of HREE content observed within the zircon rims in one sample could be associated with small scale variations in REE availability in the system. This interpretation is favoured by the abundance of zircon identified at the garnet grain boundary in contact with partial melt (Figure 3k). Thus, we conclude that the formation of the zircon rims in the studied paragneisses took place under granulite facies conditions in the presence of partial melt.

Pronounced negative Eu anomalies observed in all zircon rims imply their formation in the presence of plagioclase [75] (Figure 8). However, the weaker Eu anomalies observed in some rims in samples MJ18-05A and MJ18-02A may indicate that plagioclase was a minor constituent of the assemblage. The depletion in LREE, commonly with concentrations below the detection limit, is observed in all samples. Abnormally low LREE concentration was noticed only in the sample MJ18-02A (Figure 8c, Table S6). Such a pattern is typically developed during zircon growth in an assemblage rich in LREE-bearing minerals like monazite, allanite and/or titanite [81]. Since the monazite is present in all three samples of migmatitic paragneisses (Figure 3i), it can control the LREE budget to some extent. Moreover, to a lesser extent, titanite controls LREE uptake in metamorphic rocks [81], which may be a key factor at the late stage of exhumation, since it widely replaces rutile in the vicinity of zircon in all the studied samples. Additionally, in the sample MJ18-02A, LREE-bearing carbonates have been found within a neosome (Figure 31). Interestingly, zircon rims in this sample display the lowest concentrations of REE (Figure 8c), suggesting that the presence of the LREE-bearing carbonates could have also affected the overall REE distribution.

Although zircon from the amphibolite (MJ18-01) is commonly overgrown by a CL-bright rim, the textural resemblance with zircon from paragneisses (Figure 6) suggests a similar process leading to the formation of these rims in the presence of melt/fluid [82]. Interestingly, in this lithology, 
the zircon cores and rims form a coherent group with moderate variations of M-HREE (Figure 8d). Also, U-Pb isotopic systematics and obtained ages do not show the difference between the cores and rims. These phenomena can be interpreted in two ways. Either the zircon rims grew at the expense of the cores, but during their formation, the $\mathrm{U}-\mathrm{Pb}$ record in the cores was (nearly) totally reset, or both the cores and rims grew under similar conditions (similar REE availability) in a limited time range that is beyond the resolution of the applied dating technique. Regardless of the interpretation, we conclude that the obtained Early Ordovician age of both the cores and rims reflect the same metamorphic event. Thus, it can be stated that the zircon rims from the migmatitic paragneisses and entire zircon grains from the amphibolite were formed under granulite facies conditions, probably in the presence of melt.

The zircon rims from three migmatitic paragneisses yielded lower intercept ages of $474.8 \pm 5.8$, $479.5 \pm 2.7$ and $473.0 \pm 4.9$ Ma for the samples MJ18-05A, MJ18-05B and MJ18-02A, respectively. Lower intercept ages are thought to provide the estimates on the minimum age of metamorphism [83]. The concordia age of $469.1 \pm 4.5 \mathrm{Ma}$ calculated for the sample MJ18-05A overlaps within the error with the two younger lower intercept ages, which enhances the reliability of these age estimates, and may reflect the minimum melting age. Furthermore, both the lower intercept age of $474.8 \pm 9.0 \mathrm{Ma}$ and the calculated concordia age of $471.7 \pm 3.4 \mathrm{Ma}$ for zircons from the amphibolite are statistically identical and overlap within the error with the ages reported for the paragneisses. The two concordant ages of $646 \pm 25$ and $445 \pm 11$ Ma reported from the garnet amphibolite stand out from the cluster of Caledonian ages. While the older age of c. $646 \mathrm{Ma}$ remains enigmatic, the younger age of c. $445 \mathrm{Ma}$ could be related to the late exhumation stage, since Grimmer et al. [26] reported the age of c. $434 \mathrm{Ma}$ from mylonites and pegmatites of the Middle and Upper part of the SNC in the Saxnäs area. This age was interpreted as pinpointing the exhumation to mid-crustal levels. In conclusion, these ages could date relevant events in the evolution of the garnet amphibolites (and their host rock), but no meaningful conclusions can be drawn based on a single analysis from the reported dataset.

While the broad range of zircon core ages in the paragneisses reflects the age of the detrital input in the sedimentary protolith, the youngest analysed cores suggest the maximum depositional age of $>600 \mathrm{Ma}$ (Figure 7). However, based on the obtained dataset, it is impossible to unequivocally estimate the protoliths' ages.

\subsection{Tectonic Remarks}

The obtained Early Ordovician ages for both the paragneisses and garnet amphibolite from Kittelfjäll fill a spatial and temporal gap in the geochronological record of metamorphism within the SNC between Vaimok and Tsäkkok in the north and Saxnäs together with northern and west-central Jämtland localities in the south. Hence, they support the previously drawn hypotheses about the gradual decrease in ages due to, e.g., oblique collision between Baltica and an island arc or the subduction of an uneven Baltosacandian margin [6,17,20,40]. Interestingly, the obtained zircon ages match the recently reported monazite age from the nearby Saxnäs locality interpreted to date the peak metamorphism [25]. On the other hand, it has been demonstrated in the course of this work that the dated zircon from Kittelfjäll is unequivocally formed during post peak decompression and melting. This discrepancy can be explained as an effect of rapid decompression from the peak pressure stage to granulite facies conditions, or monazite in the paragneiss from Saxnäs has also been formed upon decompression from the peak pressure conditions, but still under a relatively high-pressure. One possible way to shed more light on this problem is to obtain the ages of zircon from Saxnäs and monazite from Kittelfjäll, and possibly to use additional geochronometry (e.g., the Lu-Hf system), which would help to resolve the enigma. Notwithstanding this speculation, Kittelfjäll is currently the northernmost reasonably well-dated locality of the pervasively partially molten SNC resembling its classical localities in Jämtland, but the obtained ages are closer to those known from the generally melt-free lithologies of the Vaimok and Tsäkkok (U)HP lenses in Norrbotten. This dating campaign also demonstrates that much more detailed geochronological work is required to fully comprehend this particular part of the SNC and its parental orogenic belt. 


\section{Conclusions}

The textural observations of the migmatitic paragneisses and the garnet amphibolite from Kittelfjäll, coupled with trace element geothermometry, U-Pb dating and REE analyses of zircon lead to the following conclusions:

1. The migmatitic paragneisses preserve remnants of the peak pressure mineral assemblage. The following exhumation and dehydration- and decompression-driven migmatization profusely overprinted the primary (U)HP mineral assemblage under granulite and amphibolite facies conditions.

2. The migmatitic paragneisses from Kittelfjäll show a petrological resemblance to metasediments representing the Seve Nappe Complex in Jämtland and other localities in southern Västerbotten. However, they are significantly different compared to the Seve Nappe Complex metasediments in Norrbotten. Despite the petrological differences between the Seve Nappe Complex in Kittelfjäll and Norrbotten, the speculated age of peak pressure metamorphism of $\geq 480 \mathrm{Ma}$ corresponds to the age of eclogite facies metamorphism known from Norrbotten.

3. The majority of the metamorphic zircon rims in the paragneisses originated from partial melt crystallization and/or dissolution-reprecipitation. Hence, the obtained lower intercept ages of $474.8 \pm 5.8,479.5 \pm 2.7$, and $473.0 \pm 4.9$ Ma reflect the timing of the granulite facies metamorphism and related migmatization. The single concordia age of $469.1 \pm 4.5 \mathrm{Ma}$ obtained from the paragneisses presumably represents the minimum melting age.

4. The zircon from the garnet amphibolite yielded the concordia age of $471.7 \pm 3.4 \mathrm{Ma}$, interpreted as growth under granulite facies conditions, which is in agreement with the ages obtained from the host paragneisses.

5. The protolith of the studied garnet amphibolite could have been peridotitic, which is only locally expressed by relict $\mathrm{Cr}$-rich paragenesis, including $\mathrm{Cr}$-garnet and chromite.

6. The obtained age of migmatization matches the observed age gradient of metamorphism from the Late Ordovician/early Silurian period in the south to the Early Ordovician/late Cambrian period in the north of the Seve Nappe Complex of the Scandinavian Caledonides.

Supplementary Materials: The following are available online at http://www.mdpi.com/2075-163X/10/4/295/s1; Table S1: GPS coordinates and bulk composition; Table S2a: EMP analyses of garnet from paragneiss; Table S2b: EMP analyses of K-feldspar and plagioclase from paragneiss; Table S2c: EMP analyses of mica from paragneiss; Table S3a: EMP analyses of clinopyroxene and amphibole from amphibolite; Table S3b: EMP analyses of garnet from amphibolite; Table S3c: EMP analyses of chromite from amphibolite; Table S4: EMP analyses of rutile and results of Zr-in-Rt thermometry; Table S5a: Summary of the U-Pb zircon analyses from the sample MJ18-05A; Table S5b: Summary of the U-Pb zircon analyses from the sample MJ18-05B; Table S5c: Summary of the U-Pb zircon analyses from the sample MJ18-02A; Table S5d: Summary of the U-Pb zircon analyses from the sample MJ18-01; Table S6a: REE analyses of zircon from the sample MJ18-05A; Table S6b: REE analyses of zircon from sample MJ18-05B; Table S6c: REE analyses of zircon from the sample MJ18-02A; Table S6d: REE analyses of zircon from the sample MJ18-01.

Author Contributions: Initiation of the project, M.B. and J.M.; fieldwork, M.B. and J.M; acquisition and further processing of the EMP data, A.W. and M.B.; sample crushing, zircon separation and mount preparation: A.Z.; acquisition and further processing of the LA-ICPMS data, M.S. M.B. and K.W.; writing-original draft preparation, M.B.; writing—review and editing, J.M and K.W.; visualization, M.B.; supervision, J.M.; funding acquisition, J.M. All authors have read and agreed to the published version of the manuscript.

Funding: This research was funded by Jarosław Majka, National Science Centre "CALSUB" grant number 2014/14/E/ST10/00321 and Michał Bukała, The Polish National Agency for the Academic Exchange scholarship no. PPN/IWA/2018/1/00046/U/0001.

Acknowledgments: The authors are grateful to C.J. Garrido and M. Janák for fruitful discussions. M. Sęk is acknowledged for the photographs of the studied samples, whereas P. Derkowski is acknowledged for providing CL images. This is Vegacenter contribution number \#025.

Conflicts of Interest: The authors declare no conflict of interest. 


\section{References}

1. Gee, D.G. A tectonic model for the central part of the Scandinavian Caledonides. Am. J. Sci. 1975, 275- $A, 468-515$.

2. Dallmeyer, R.D.; Gee, D.G. 40Ar/39Ar mineral dates from retrogressed eclogites within the Baltoscandian miogeocline: Implications for a polyphase Caledonian orogenic evolution. Geol. Soc. Am. Bulletic 1986, 97, 26-34. [CrossRef]

3. Solyom, Z.; Andréasson, P.-G.; Johansson, I. Geochemistry of amphibolites from Mt. Sylarna, Central Scandinavian Caledonides. Geol. Föreningen i Stock. Förhandlingar 1979, 101, 17-25. [CrossRef]

4. Svenningsen, O.M. Onset of seafloor spreading in the Iapetus Ocean at $608 \mathrm{Ma}$ : Precise age of the Sarek Dyke Swarm, northern Swedish Caledonides. Precambrian Res. 2001, 110, 241-254. [CrossRef]

5. Gee, D.G.; Fossen, H.; Henriksen, N.; Higgins, A.K. From the Early Paleozoic Platforms of Baltica and Laurentia to the Caledonide Orogen of Scandinavia and Greenland. Episodes 2008, 31, 44-51. [CrossRef] [PubMed]

6. Gee, D.G.; Janák, M.; Majka, J.; Robinson, P.; Van Roermund, H.L.M. Subduction along and within the Baltoscandian margin during closing of the Iapetus Ocean and Baltica- Laurentia collision. Lithosphere 2012, 5, 169-178. [CrossRef]

7. Cuthbert, S.J.; Carswell, D.A.; Krogh Ravna, E.J.; Wain, A. Eclogites and eclogites in the Western Gneiss Region, Norwegian Caledonides. Lithos 2000, 52, 165-195. [CrossRef]

8. Froitzheim, N.; Miladinova, I.; Janák, M.; Kullerud, K.; Krogh Ravna, E.J.; Majka, J.; Fonseca, R.O.C.; Münker, C.; Nagel, T.J. Devonian subduction and syncollisional exhumation of continental crust in Lofoten, Norway. Geology 2016, 44, 223-226. [CrossRef]

9. Krogh Ravna, E.J.; Roux, M.R.M. Metamorphic evolution of the Tønsvika Eclogite, Tromsø Nappe-Evidence for a new UHPM province in the Scandinavian Caledonides. Int. Geol. Rev. 2006, 48, 861-881. [CrossRef]

10. Janák, M.; Krogh Ravna, E.J.; Kullerud, K. Contraining peak P-T conditions in UHP eclogites: Calculates phase equilibria in kyanite- and phengite-bearing eclogite of the Tromsø Nappe, Norway. J. Metamorph. Geol. 2012, 30, 377-396. [CrossRef]

11. Ziemniak, G.; Kośmińska, K.; Petrík, I.; Janák, M.; Walczak, K.; Manecki, M.; Majka, J. Th-U-total Pb monazite geochronology records Ordovician (444 Ma) metamorphism/partial melting and Silurian (419 Ma) thrusting in the Kåfjord Nappe, Norwegian Arctic Caledonides. Geol. Carpathica 2019, 70, 494-511. [CrossRef]

12. Andréasson, P.G. The Baltoscandian Margin in Neoproterozoic-early Palaeozoic times. Some constraints on terrane derivation and accretion in the Arctic Scandinavian Caledonides. Tectonophysics 1994, 231, 1-32. [CrossRef]

13. Zachrisson, E. The westerly extension of Seve rocks within the Seve-Köli Nappe Complex in the Scandinavian Caledonides. Geol. Föreningen i Stock. Förhandlingar 1973, 95, 243-251. [CrossRef]

14. Klonowska, I.; Janák, M.; Majka, J.; Petrík, I.; Froitzheim, N.; Gee, D.G.; Sasinková, V. Microdiamond on Åreskutan confirms regional UHP metamorphism in the Seve Nappe Complex of the Scandinavian Caledonides. J. Metamorph. Geol. 2017, 35, 541-564. [CrossRef]

15. Clos, F.; Gilio, M.; Roermund, H.L.M. Fragments of deeper parts of the hanging wall mantle preserved as orogenic peridotites in the central belt of the Seve Nappe, Sweden. Lithos 2014, 192-195, 8-20. [CrossRef]

16. Brueckner, H.K.; Van Roermund, H.L.M. Concurrent HP metamorphism on both margins of Iapetus: Ordovician ages for eclogites and garnet pyroxenites from the Seve Nappe Complex, Swedish Caledonides. J. Geol. Soc. 2007, 164, 117-128. [CrossRef]

17. Fassmer, K.; Klonowska, I.; Walczak, K.; Andersson, B.; Froitzheim, N.; Majka, J.; Fonseca, R.O.C.; Münker, C.; Janák, M.; Whitehouse, M. Middle Ordovician subduction of continental crust in the Scandinavian Caledonides: An example from Tjeliken, Seve Nappe Complex, Sweden. Contrib. Mineral. Petrol. 2017, 172, 103. [CrossRef]

18. Ladenberger, A.; Be'eri-Shlevin, Y.; Claesson, S.; Gee, D.G.; Majka, J.; Romanova, I.V. Tectonometamorphic evolution of the Åreskutan Nappe-Caledonian history revealed by SIMS U-Pb zircon geochronology. In New Perspectives on the Caledonides of Scandinavia and Related Areas; Corfu, F., Gasser, D., Chew, D.M., Eds.; Geological Society: London, UK, 2014; pp. 337-368.

19. Albrecht, L.G. Early Structural and Metamorphic Evolution of the Scandinavian Caledonides: A Study of the Eclogite-Bearing Seve Nappe Complex at the Arctic Circle, Sweden; Lund University: Lund, Sweden, 2000. 
20. Bukała, M.; Klonowska, I.; Barnes, C.; Majka, J.; Kośmińska, K.; Janák, M.; Fassmer, K.; Broman, C.; Luptáková, J. UHP metamorphism recorded by phengite eclogite from the Caledonides of northern Sweden: P-T path and tectonic implications. J. Metamorph. Geol. 2018, 36, 547-566. [CrossRef]

21. Mørk, M.B.E.; Kullerud, K.; Stabel, A. Sm-Nd dating of Seve eclogites, Norrbotten, Sweden-Evidence for early Caledonian (505 Ma) subduction. Contrib. Mineral. Petrol. 1988, 99, 344-351. [CrossRef]

22. Root, D.; Corfu, F. U-Pb geochronology of two discrete Ordovician high-pressure metamorphic events in the Seve Nappe Complex, Scandinavian Caledonides. Contrib. Mineral. Petrol. 2012, 163, 769-788. [CrossRef]

23. Barnes, C.; Majka, J.; Schneider, D.; Walczak, K.; Bukała, M.; Kośmińska, K.; Tokarski, T.; Karlsson, A. High-spatial resolution dating of monazite and zircon reveals the timing of subduction-Exhumation of the Vaimok Lens in the Seve Nappe Complex (Scandinavian Caledonides). Contrib. Mineral. Petrol. 2019, 174, 5. [CrossRef]

24. Wiliams, I.S.; Claesson, S. Isotopic evidence for the Precambrian provenance and Caledonian metamorphism of high grade paragneisses from the Seve Nappes, Scandinavian Caledonides. II. Ion microprobe zircon U-Th-Pb. Contrib. Mineral. Petrol. 1987, 97, 205-217. [CrossRef]

25. Petrík, I.; Janák, M.; Klonowska, I.; Majka, J.; Froitzheim, N.; Yoshida, K.; Sasinková, V.; Konečny, P.; Vaculovič, T. Monazite behaviour during metamorphic evolution of a diamond- bearing gneiss: A case study from the Seve Nappe Complex, Scandinavian Caledonides. J. Petrol. 2019, 60, 1773-1796. [CrossRef]

26. Grimmer, J.C.; Glodny, J.; Drüppel, K.; Greiling, R.O.; Kontny, A. Early- to mid-Silurian extrusion wedge tectonics in the central Scandinavian Caledonides. Geology 2015, 43, 347-350. [CrossRef]

27. Majka, J.; Rosén, Å.; Janák, M.; Froitzheim, N.; Klonowska, I.; Manecki, M.; Sasinková, V.; Yoshida, K. Microdiamond dicovered in the Seve Nappe (Scandinavian Caledonides) and its exhumation by the "vacuum-cleaner" mechanism. Geology 2014, 42, 1107-1110. [CrossRef]

28. Klonowska, I.; Majka, J.; Janák, M.; Gee, D.G.; Ladenberger, A. Pressure-temperature evolution of a kyanite-garnet pelitic gneiss from Åreskutan: Evidence of ultra-high-pressure metamorphism of the Seve Nappe Complex, west-central Jämtland, Swedish Caledonides. In New Perspectives on the Caledonides of Scandinavia and Related Areas; Corfu, F., Gasser, D., Chew, D.M., Eds.; Geological Society: London, UK, 2014; pp. 321-336.

29. Majka, J.; Be'eri-Shlevin, Y.; Gee, D.G.; Ladenberger, A.; Claesson, S.; Konečny, P.; Klonowska, I. Multiple monazite growth in the Åreskutan migmatite: Evidence for a polymetamorphic Late Ordovician to Late Silurian evolution in the Seve Nappe Complex of west-central Jämtland, Sweden. J. Geosci. 2012, 57, 3-23. [CrossRef]

30. Claesson, S. Caledonian metamorphism of Proterozoic Seve rocks on Mt. Åreskutan, southern Swedish Caledonides. Geol. Föreningen i Stock. Förhandlingar 1982, 103, 291-304. [CrossRef]

31. Gromet, L.P.; Sjöström, H.; Bergman, S.; Claesson, S.; Essex, R.M.; Andréasson, P.-G.; Albrecht, L.G. Contrasting ages of metamorphism in the Seve nappes: U-Pb results from the central and northern Swedish Caledonides. GFF 1996, 118, 36-37. [CrossRef]

32. Kullerud, K. Orogin and Tectonometamorphic Evolution of the Eclogites in the Tsäkkok Lens (Seve Nappes), Southern Norrbotten Sweden; University of Oslo: Oslo, Norway, 1987.

33. Nicholson, R. An eclogite from the Caledonides of southern Norrbotten. Nor. Geol. Tidsskr. 1984, 64, 165-169.

34. Stephens, M.B.; Van Roermund, H.L.M. Occurence of glaucophane and crossite in eclogites of the Seve Nappes, southern Norrbotten Caledonides, Sweden. Nor. Geol. Tidsskr. 1984, 64, 155-163.

35. Bukała, M.; Barnes, C.; Jeanneret, P.; Majka, J.; Klonowska, I.; Kośmińska, K. The interplay between fluid and fracturing: Seismometamorphic evolution of Tsäkkok eclogites, Scandinavian. In Proceedings of the 21st EGU General Assembly, Vienna, Austria, 7-12 April 2019. Geophysical Research Abstracts.

36. Essex, R.M.; Gromet, L.P.; Andréasson, P.-G.; Albrecht, L.G. Early Ordovician U-Pb metamorphic ages of the eclogite-bearing Seve Nappes, Northern Scandinavian Caledonides. J. Metamorph. Geol. 1997, 15, 665-676. [CrossRef]

37. Zachrisson, E.; Sjöstrand, T. Bedrock Map 22E Frostviken, 1:50000; SGU Ai 44; SGU: Uppsala, Sweden, 1990.

38. Zwart, H.J. Structure and metamorphism in the Seve-Köli Nappe Complex (Scandinavian Caledonides) and its implications concerning the formation of metamorphic nappes. In Géologie des Domains Cristallins. Centenaire de la Société Géologique de Belgique; Duchesne, J.C., Bellière, J., Eds.; Société Géologique de Belgique: Liège, Belgium, 1974; pp. 129-144. 
39. Van Roermund, H.L.M.; Barker, E. Structure and metamorphism of the Tången-Inviken area, seve nappes, central scandinavian caledonides. GFF 1984, 105, 301-319. [CrossRef]

40. Brueckner, H.K.; Van Roermund, H.L.M. Dunk tectonics: A multiple subduction/eduction model for the evolution of the Scandinavian Caledonides. Tectonics 2004, 23, TC2004. [CrossRef]

41. Majka, J.; Janák, M.; Andersson, B.; Klonowska, I.; Gee, D.G.; Rosén, Å.; Kośmińska, K. Pressure-temperature estimates on the Tjeliken eclogite: New insights into the (ultra)-high-pressure evolution of the Seve Nappe Complex in the Scandinavian Caledonides. In New Perspectives on the Caledonides of Scandinavia and Related Areas; Corfu, F., Gasser, D., Chew, D.M., Eds.; Geological Society: London, UK, 2014; pp. 369-384.

42. Janák, M.; Van Roermund, H.L.M.; Majka, J.; Gee, D.G. UHP metamorphism recorded by kyanite-bearing eclogite in the Seve Nappe Complex of nothern Jämtland, Swedesh Caledonites. Gondwana Res. 2013, 23, 865-879. [CrossRef]

43. Klonowska, I.; Janák, M.; Majka, J.; Froitzheim, N.; Kośmińska, K. Eclogite and garnet pyroxenite from Stor Jougdan, Seve Nappe Complex, Sweden: Implications for UHP metamorphism of allochthons in the Scandinavian Caledonides. J. Metamorph. Geol. 2016, 34, 103-119. [CrossRef]

44. Gilio, M.; Clos, F.; Van Roermund, H.L.M. The Friningen Garnet Peridotite (central Swedish Caledonides). A good example of the charaacteristic PTt path of a cold mantle wedge garnet peridotite. Lithos 2015, 230, 1-16. [CrossRef]

45. Bender, H.; Glodny, J.; Ring, U. Absolute timing of Caledonian orogenic wedge assembly, Central Sweden, constrained by Rb-Sr multi-mineral isochron data. Lithos 2019, 344-345, 339-359. [CrossRef]

46. Biermann, C. Investigations into the Development of Microstructures in Amphibole Bearing Rocks from the Seve-Köli Nappe Complex; Leiden University: Leiden, The Netherlands, 1979.

47. Trouw, R.A.J. Structural geology ofthe Marsfjällen area Caledonides of Västerbotten Sweden. Arsb. Sver. Geol. Unders. 1973, 689, 1-115.

48. Petrus, J.A.; Kamber, B.S. VizualAge: A Novel Approach to Laser Ablation ICP-MS U-Pb Geochronology Data Reduction. Geostand. Geoanalytical Res. 2012, 36, 247-270. [CrossRef]

49. Wiedenbeck, M.; Alle, P.; Corfu, F.; Meier, M.; Oberli, F.; Von Quadt, A.; Roddick, J.C.; Spiegel, W. Three Natural Zircon Standards for U-Th-Pb, Lu-Hf, Trace Element and Ree Analyses. Geostand. Newsl. 1995, 19, 1-23. [CrossRef]

50. Jackson, S.E.; Pearson, N.J.; Griffin, W.L.; Belousova, E.A. The application of laser ablation-inductively coupled plasma-mass spectrometry to in situ U-Pb zircon geochronology. Chem. Geol. 2004, 211, 47-69. [CrossRef]

51. Sláma, J.; Košler, J.; Condon, D.J.; Crowley, J.L.; Gerdes, A.; Hanchar, J.M.; Horstwood, M.S.A.; Morris, G.A.; Nasdala, L.; Norberg, N.; et al. Plešovice zircon-A new natural reference material for U-Pb and Hf isotopic microanalysis. Chem. Geol. 2008, 249, 1-35. [CrossRef]

52. Black, L.P.; Kamo, S.L.; Allen, C.M.; Davis, D.W.; Aleinikoff, J.N.; Valley, J.W.; Mundil, R.; Campbell, I.H.; Korsch, R.J.; Williams, I.S.; et al. Improved 206Pb/238U microprobe geochronology by the monitoring of a trace-element-related matrix effect; SHRIMP, ID-TIMS, ELA-ICP-MS and oxygen isotope documentation for a series of zircon standards. Chem. Geol. 2004, 205, 115-140. [CrossRef]

53. Ludwig, K.R. User's Manual for Isoplot 3.75, a Geochronological Toolkit for Microsoft Excel; Berkeley Geochronology Center: Berkeley, CA, USA, 2012; Available online: http://www.bgc.org/isoplot_etc/isoplot.html (accessed on 6 February 2015).

54. Wiedenbeck, M.; Hanchar, J.M.; Peck, W.H.; Sylvester, P.; Valley, J.; Whitehouse, M.; Kronz, A.; Morishita, Y.; Nasdala, L.; Fiebig, J.; et al. Further Characterisation of the 91500 Zircon Crystal. Geostand. Geoanalytical Res. 2007, 28, 9-39. [CrossRef]

55. Sun, S.; McDonough, W.F. Chemical and isotopic systematics of oceanic basalts: Implications for mantle composition and processes. In Magmatism in the Ocean Basins; Saunders, A.D., Norry, M.J., Eds.; Geological Society: London, UK, 1989; pp. 313-345.

56. Lanari, P.; Vidal, O.; De Andrade, V.; Dubacq, B.; Lewin, E.; Grosch, E.G.; Schwartz, S. XMapTools: A MATLAB(C-based program for electron microprobe X-ray image processing and geothermobarometry. Comput. Geosci. 2014, 62, 227-240. [CrossRef]

57. Tomkins, H.S.; Powell, R.; Ellis, D.J. The pressure dependence of the zirconium-in-rutile thermometer. J. Metamorph. Geol. 2007, 25, 703-713. [CrossRef] 
58. Gee, D.G.; Ladenberger, A.; Dahlqvist, P.; Majka, J.; Be'eri-Shlevin, Y.; Frei, D.; Thomsen, T. The Baltoscandian margin detrital zircon signatures of the central Scandes. In New Perspectives on the Caledonides of Scandinavia and Related Areas; Corfu, F., Gasser, D., Chew, D.M., Eds.; Geological Society: London, UK, 2014; pp. 131-155.

59. Gee, D.G.; Andrésson, P.-G.; Lorenz, H.; Frei, D.; Majka, J. Detrital zircon signatures of the Baltoscandian margin along the Arctic Circle Caledonides in Sweden: The Sveconorwegian connection. Precambrian Res. 2015, 265, 40-56. [CrossRef]

60. Lang, H.M.; Gilotti, J.A. Partial melting of metapelites at ultrahigh-pressure conditions, Greenland Caledonides. J. Metamorph. Geol. 2007, 25, 129-147. [CrossRef]

61. Thompson, A.B. Dehydration melting of pelitic rocks and the generation of $\mathrm{H}_{2} \mathrm{O}$-undersaturated granitic liquids. Am. J. Sci. 1982, 282, 1567-1595. [CrossRef]

62. Vielzeuf, D.; Holloway, J.R. Experimental determination of the fluid-absent melting relations in the pelitic system. Contrib. Mineral. Petrol. 1988, 98, 257-276. [CrossRef]

63. Indares, A.; Dunning, G. Partial melting of high-P-T metapelites from the Tshenukutish Terrane (Grenville Province): Petrography and U-Pb geochronology. J. Petrol. 2001, 42, 1547-1565. [CrossRef]

64. Meinhold, G. Rutile and its applications in earth sciences. Earth-Sci. Rev. 2010, 102, 1-28. [CrossRef]

65. Van Roermund, H.L.M. On eclogites from the Seve Nappe, N. Jämtland, Central Scandinavian Caledonides; University of Utrecht: Utrecht, The Netherlands, 1982.

66. Boland, J.N.; Van Roermund, H.L.M. The decomposition of natural omphcite into pyroxene-plagioclase symplectites- a case of discontinuous precipitation. In Electron Microscopy; Brederoo, P., Boom, G., Eds.; European Congres on Electron Microscopy: Leiden, The Netherlands, 1980; pp. 458-459.

67. Haggerty, S.E. Upper mantle mineralogy. J. Geodyn. 1995, 20, 331-364. [CrossRef]

68. Fleet, M.E.; Angeli, N.; Pan, Y. Oriented chlorite lamellae in chromite from Pedra Branca Mafic-Ultramafic complex, Ceara, Brazil. Am. Mineral. 1993, 78, 68-74.

69. Medaris, L.G.J.; Beard, B.L.; Jelínek, E. Mantle-Derived, UHP Garnet Pyroxenite and Eclogite in the Moldanubian Gföhl Nappe, Bohemian Massif: A Geochemical Review, New P-T Determinations, and Tectonic Interpretation. Int. Geol. Rev. 2006, 48, 765-777. [CrossRef]

70. Kullerud, K.; Stephens, M.B.; Zachrisson, E. Pillow lavas as protoliths for eclogites: Evidence from a late Precambrin-Cambrian continental margin, Seve Nappes, Scandinavian Caledonides. Contrib. Mineral. Petrol. 1990, 105, 1-10. [CrossRef]

71. Spandler, C.; Hermann, J.; Rubatto, D. Exsolution of thortveitite, yttrialite and xenotime during low temperature recrystallization of zircon from New Caledonia, and their significance for trace element incorporation in zircon. Am. Mineral. 2004, 89, 1795-1806. [CrossRef]

72. Ewing, T.; Hermann, J.; Rubatto, D. The robustness of the Zr-in-rutile and Ti-in-zircon thermometers during high-temperature metamorphism (Ivrea-Verbano Zone, norhtern Italy). Contrib. Mineral. Petrol. 2013, 165, 757-779. [CrossRef]

73. Gauthiez-Putallaz, L.; Rubatto, D.; Hermann, J. Dating prograde fluid pulses during subduction by in situ $\mathrm{U}-\mathrm{Pb}$ and oxygen isotope analysis. Contrib. Mineral. Petrol. 2016, 171, 15. [CrossRef]

74. Rubatto, D.; Gebauer, D. Use of cathodoluminescence for U-Pb zircon dating by ion microprobe: Some examples from the Western Alps. In Cathodoluminescence in Geosciences; Pagel, M., Barbin, V., Blanc, P., Ohnenstetter, D., Eds.; Springer: Berlin/Heidelberg, Germany, 2000; pp. 373-400.

75. Schaltegger, U.; Fanning, M.; Günter, D.; Maurin, J.C.; Schulmann, K.; Gebauer, D. Growth, annealing and recrystallization of zircon and preservation of monazite in high-grade metamorphism: Conventional and in situ $\mathrm{U}-\mathrm{Pb}$ isotope, cathodoluminescence and microchemical evidence. Contrib. Mineral. Petrol. 1999, 134, 186-201. [CrossRef]

76. Hermann, J.; Rubatto, D. Relating zircon and monazite domains to garnet growth zones: Age and duration of granulite facies metamorphism in the Val Malenco lower crust. J. Metamorph. Geol. 2003, 21, 833-852. [CrossRef]

77. Tomaschek, F.; Kennedy, A.A.; Villa, I.M.; Lagos, M.; Ballhaus, C. Zircon from Syros, Cyclades, Greece-Recrystallization and mobilization of zircon during high-pressure metamorphism. J. Petrol. 2001, 54, 343-385. [CrossRef]

78. Geisler, T.; Pidgeon, R.T.; Kurtz, R.; Bronswijk, W.; Schleicher, H. Experimental hydrothermal alteration of partially metamict zircon. Am. Mineral. 2003, 88, 1496-1543. [CrossRef] 
79. Vavra, G.; Schmid, R.; Gebauer, D. Internal morphology, habit and U-Th-Pb microanalysis of amphibolite-to-granulite facies zircons: Geochronology of the Ivrea Zone (Southern Alps). Contrib. Mineral. Petrol. 1999, 134, 380-404. [CrossRef]

80. Kohn, M.J.; Kelly, N.M. Petrology and geochronology of metamorphic zircon. In Microstructural Geochronology: Planetary Records Down to Atom Scale; Moser, D.E., Corfu, F., Darling, J.R., Reddy, S.M., Tait, K., Eds.; American Geophysical Union: Washington, DC, USA, 2018; pp. 35-61. ISBN 9781119227250.

81. Rubatto, D.; Hermann, J.; Berger, A.; Engi, M. Protracted fluid-induced melting during Barrovian metamorphism in the Central Alps. Contrib. Mineral. Petrol. 2009, 158, 703-722. [CrossRef]

82. Walczak, K.; Anczkiewicz, R.; Szczepański, J.; Rubatto, D.; Košler, J. Combined garnet and zircon geochronology of the ultra-high temperature metamorphism: Constraints on the rise of the Orlica-Śnieżnik Dome, NE Bohemian Massif, SW Poland. Lithos 2017, 292-293, 388-400. [CrossRef]

83. Mezger, K.; Krogstad, E.J. Interpretation of discordant U-Pb zircon ages: An evaluation. J. Metamorph. Geol. 1997, 15, 127-140. [CrossRef]

(C) 2020 by the authors. Licensee MDPI, Basel, Switzerland. This article is an open access article distributed under the terms and conditions of the Creative Commons Attribution (CC BY) license (http://creativecommons.org/licenses/by/4.0/). 